Article

\title{
Exploring the Dunes: The Correlations between Vegetation Cover Pattern and Morphology for Sediment Retention Assessment Using Airborne Multisensor Acquisition
}

\author{
Emiliana Valentini ${ }^{1, *}$, Andrea Taramelli ${ }^{1,2}{ }^{\infty}$, Sergio Cappucci ${ }^{3}$, Federico Filipponi ${ }^{1}(\mathbb{D}$ and \\ Alessandra Nguyen Xuan ${ }^{1}$ \\ 1 Institute for Environmental Protection and Research (ISPRA), 00144 Rome, Italy; \\ andrea.taramelli@iusspavia.it (A.T.); federico.filipponi@isprambiente.it (F.F.); \\ alessandra.nguyenxuan@isprambiente.it (A.N.X.) \\ 2 Istituto Universitario di Studi Superiori di Pavia (IUSS) 27100 Pavia, Italy \\ 3 National Agency for New Technologies Energy and Sustainable Development (ENEA), 00123 Rome, Italy; \\ sergio.cappucci@enea.it \\ * Correspondence: emiliana.valentini@isprambiente.it; Tel.: +39-0650074778
}

Received: 17 March 2020; Accepted: 8 April 2020; Published: 12 April 2020

\begin{abstract}
Coastal sand dunes are highly dynamic aeolian landforms where different spatial patterns can be observed due to the complex interactions and relationships between landforms and land cover. Sediment distribution related to vegetation types is explored here on a single ridge dune system by using an airborne hyperspectral and light detection and ranging (LiDAR) remote sensing dataset. A correlation model is applied to describe the continuum of dune cover typologies, determine the class metrics from landscape ecology and the morphology parameters, and extract the relationship intensity among them. As a main result, the mixture of different vegetation types such as herbaceous, shrubs, and trees classes shows to be a key element for the sediment distribution pattern and a proxy for dune sediment retention capacity, and the anthropic fingerprints can play an even major role influencing both ecological and morphological features. The novelty of the approach is mostly based on the synergistic use of LiDAR with hyperspectral that allowed (i) the benefit from already existing processing methods to simplify the way to obtain thematic maps and coastal metrics and (ii) an improved detection of natural and anthropic landscape.
\end{abstract}

Keywords: beach-dune system; sediment retention; coastal sand and vegetation patterns; spectral libraries; airborne hyperspectral; LiDAR; FHyL method; Anthropocene; ecogeomorphology.

\section{Introduction}

Dunes are dynamic systems naturally subject to morphological and ecological changes. Their spatial and temporal evolution is due to several physical and biological factors [1-3] and to occasional disturbances (stochastic events) after which they tend to recover to a dynamic equilibrium [4-7]. At the initial stage, the formation of the dune is mainly driven by the availability of sediment and wind energy that enable sand accumulation and, therefore, determines the type and distribution of vegetation (primary vegetation). At a later stage, the vegetation gains relevance for growing and stabilizing the dune, trapping sand with leaves, branches, and roots (secondary and tertiary vegetation) [8,9].

Sediment distribution can be considered the result of the retention capacity of the dune environment and is due to a large number of factors, such as wind regimes, runoff, coastal current, wave energy, vegetation coverage, and coastal exploitation. The development and evolution of coastal dunes are 
led by the balance between the wind regime, sediment budget, and vegetation coverage [10-14]. Key studies [15] highlight that vegetation coverage plays a particularly important role, showing that only $15 \%-20 \%$ of vegetation coverage is sufficient to inhibit wind-blown sand transport [16-19]. In vegetated environments, biostabilizations of sediments occur in preparation for the establishment and spread of the next serial stage of succession species [20,21]. Morphometric factors related to ecological constraints, such as vegetation presence/absence and structure, are generally relevant in the coastal setting $[15,22,23]$. Concurrently, the Anthropocene fingerprint, i.e., human activities [24], has an effect on the morphological equilibrium of coastal areas and, consequently, on the distribution of water, sediments, and nutrients in coastal habitats [25].

Thus, geomorphological processes along with vegetation presence and absence jointly determine the evolution of dune systems, generally known as land-surface eco-morphodynamics [26]. In this context, the spatial relationship between sediment distribution and vegetation cover (vegetated and non-vegetated areas) within dunes is still a question that needs to be investigated, specifically finding spatial patterns $[26,27]$.

Most remote sensing studies have focused on detecting spatial patterns through the use of aerial sensors [15,28-30] and lower-resolution images [31,32], and the use of spatial variables derived from remote sensing imagery offers an ideal tool to study the relationships among vegetation type, patch distribution, and eventually crest and foot sinuosity of the dune system. In the last 20 years, some authors $[33,34]$ have provided an initial overview of the capabilities of remote sensing for coastal zone studies and, recently, other authors have focused on the estuarine environment [35]. The focus in these articles is on both low-resolution remote sensing [33,35] and the additional value of very-high-resolution hyperspectral data [23,34]. Hyperspectral remote sensing is a powerful tool for the identification of earth surface materials due to the value of continuous spectral signals in terms of band contiguity and density, as argued by authors in previous research related to this topic [36,37].

For vegetated dune fields, a number of key studies have adopted methods for analyzing color aerial photography and hyperspectral remote-sensing data. Such tools are essential to determine functional vegetation types and plant communities $[15,38]$, as well as for identifying mineral composition and texture in soil and sediment studies $[36,39,40]$.

The ability of airborne light detection and ranging (LiDAR) data to accurately represent altimetry over large areas has been demonstrated by a number of analyses [41,42]. Airborne laser altimetry is largely used to map coastal geomorphology and the geomorphic process and for analyzing the distribution of sediment and vegetation spatial patterns [43]. The typical dunes' vegetation zonation is closely related to ecomorphological gradients from the shoreline to the inland regions, and the great potential in coastal systems monitoring is the availability of synchronous acquisition of LiDAR and hyperspectral sensors to explore the relationships between dune vegetation and local dune morphology [44].

To improve the understanding of spatial patterns and relationships relevant to the sediment retention capacity exerted by the dune environment, an approach is developed in the present study for a linear correlation model based on sliding windows, to explore hypotheses that elevation, slope, vegetation cover typologies, and sinuosity are spatially correlated with sand cover abundance.

To test these hypotheses, vegetation and topographic characterizations are obtained using the FHyL (Field spectral libraries, airborne Hyperspectral imagery and LiDAR altimetry) method [30,37,45] that enables multisensory integration of observations in emerged and submerged coastal environments.

Our scientific purpose is to develop a remote sensing methodology to examine coastal dune spatial patterns: More specifically, it is not well-known how sediment is distributed in relation to the vegetation pattern from the surf zone to the later structured vegetated stages. The spatially explicit ecomorphological patterns occurring in the area should highlight the signatures of how geomorphic features including Anthropocene patches, such as buildings, houses, roads, and other anthropic activities, interact with the vegetation distribution. 


\section{Study Area}

The coastal stretch (Figure 1) is a microtidal sandy beach-lagoon system in the Circeo National Park (Central Italy) characterized by a single continuous dune ridge, approximately $22 \mathrm{~km}$ long, running parallel to the shoreline. Channels and inlets that connect the coastal lagoons naturally and artificially interrupt the continuity of the system. The beach-dune system of the Circeo National Park is the remnant of a barrier island that separated the coastal plain from the open sea during the Holocene $[46,47]$. Longshore sediment transport toward the SE is a consequence of the main NW-coming wind (Mistral). As a consequence, both the elevation and amplitude of the emerged beach-dune system increase from north to south to the maximum elevation of $28 \mathrm{~m}$ above sea level (including surface objects) and to the maximum width of $250 \mathrm{~m}$ in the southern part of the area [48].

a)

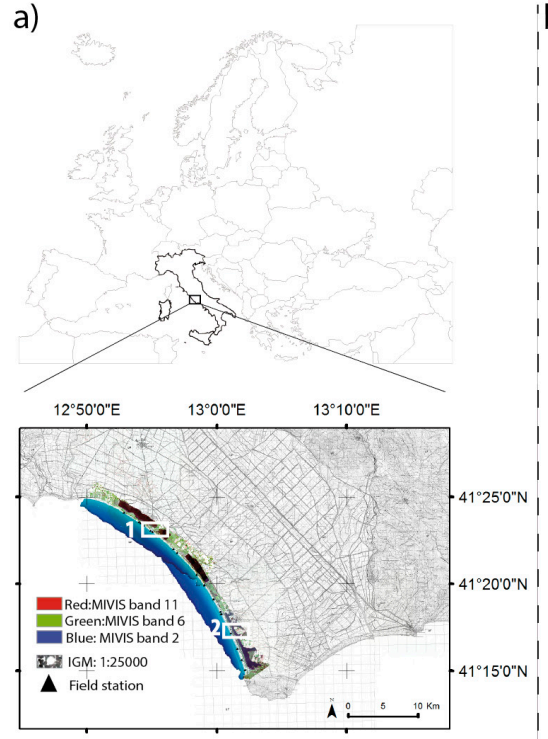

b) 1437000

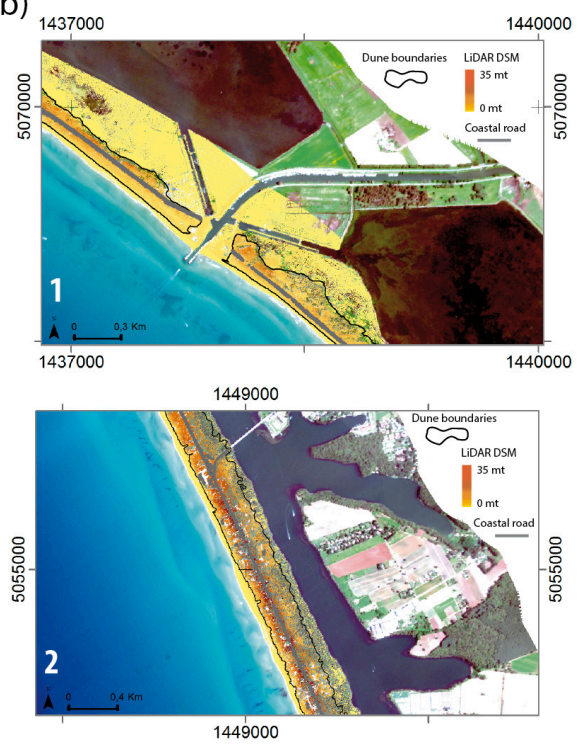

c)
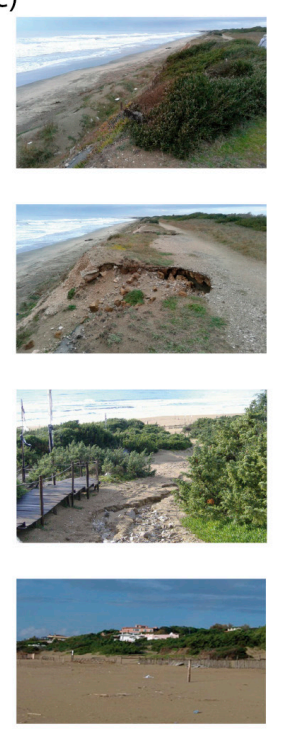

Figure 1. (a) Study area location with basic cartography and the hyperspectral Multispectral Infrared Visible Imaging Spectrometer (MIVIS) data coverage; (b) miniature 1 and 2 are the two zooms of the study area highlighted in (a), with the light detection and ranging (LiDAR) digital surface model (DSM) on MIVIS true color imagery; (c) pictures of the area taken in May 2009.

The dunes are mostly colonized by specialized coastal vegetation typical of the Mediterranean areas and characterized by a linear floristical, chorological, and phytosociological zonation from the sea landward $[20,21]$. In the 1950s, the dynamics of the system (i.e., the dynamics orthogonal to the shoreline) were blocked by the construction of the coastal road at the dune crest, and its natural morphological evolution was further stopped by increased runoff phenomena related to the soil sealing.

Due to the different exposures to wind and insolation, the dune lee side (facing the coastal lagoons) is characterized by the presence of well-structured trees and shrub vegetation, while the stoss side facing the sea is dominated by xerophytic bushes and halophytes, which can retain the sand through specialized root systems $[49,50]$. The emerged beach, mostly in the southern part of the area, is subject to management practices during summer for a better exploitation. In the northern part, the most exposed to coastal erosion, various coastal defense and nourishment interventions were carried out in the last 35 years to protect buildings and guarantee tourist activities [51,52].

The glossary used to describe the dune system metrics is graphically explained in Figure 2. 


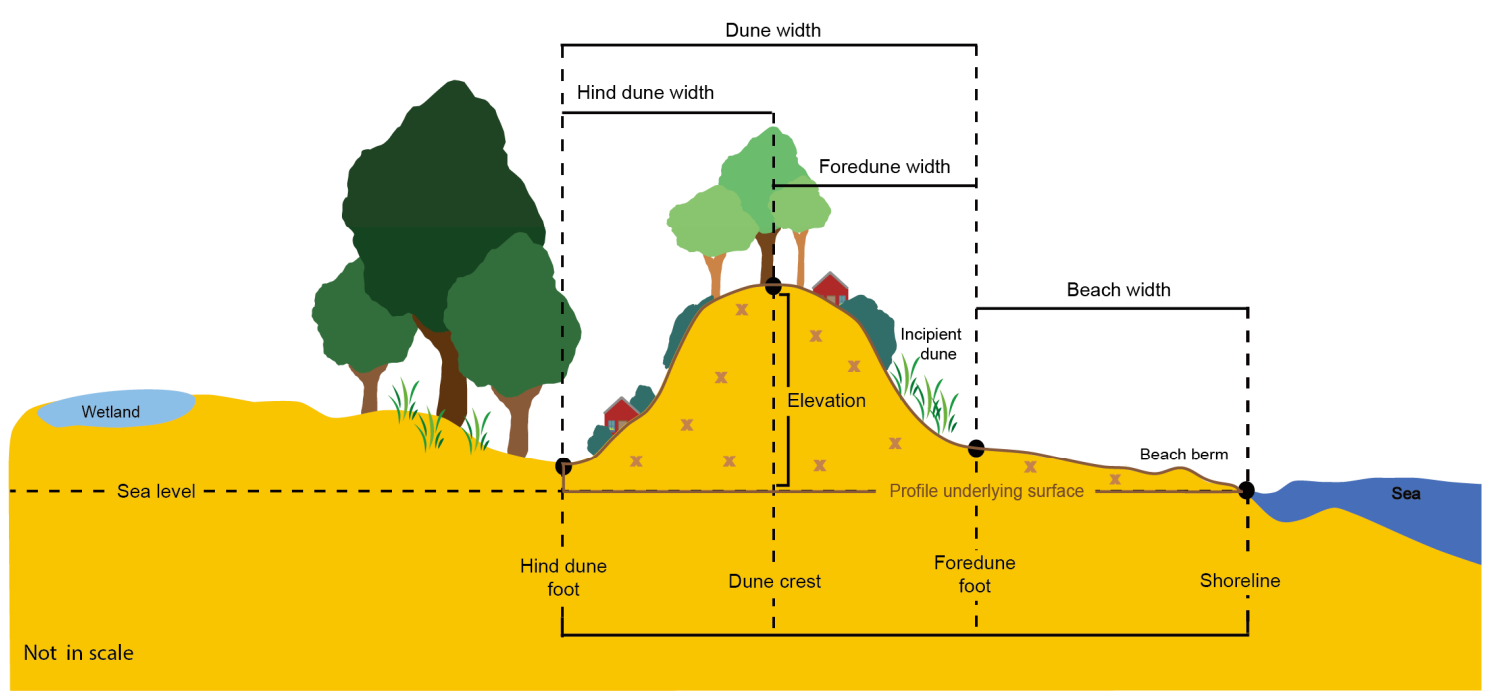

Figure 2. Dune zonation, metrics, and terminology used in the present paper. Grasses and creepers are the pioneer colonizers of sand dunes (primary species) in the succession process that stabilizes the dune foot and foredune; shrubs and short-lived trees (secondary species), and long-lived trees (tertiary species), form a protective and more stable coastal forest.

\section{Materials and Methods}

\subsection{Materials}

Two types of airborne datasets, the LiDAR altimetry and the hyperspectral imagery from Multispectral Infrared Visible Imaging Spectrometer (MIVIS) (Figure 1, Table 1, and Table 2), simultaneously acquired in May 2009, provided the base for the beach-dune system analysis. A contemporary field campaign provided a set of ground control points and hyperspectral measurements useful for groundtruthing, calibration, and validation.

Table 1. Main technical features of topographic LiDAR sensor.

\begin{tabular}{cc}
\hline \multicolumn{2}{c}{ LiDAR HawkEye II } \\
\hline Topographic Frequency & $64,000 \mathrm{~Hz}$ \\
Altitude & From 250 to $500 \mathrm{~m}$ \\
Swath & From 100 to $330 \mathrm{~m}$ \\
Topographic point density & From 1 to 4 points for m² \\
Accuracy of Topographic survey & Horizontal: $\pm 0.5 \mathrm{~m}$ \\
& (Vertical: $\pm 0.15 \mathrm{~m}$ \\
\hline
\end{tabular}

Table 2. Technical features of hyperspectral MIVIS sensor.

\begin{tabular}{ccc}
\hline \multicolumn{3}{c}{ MIVIS - Multispectral Infrared Visible Imaging Spectrometer } \\
\cline { 2 - 3 } & Wavelength $(\mu \mathrm{m})$ & Spectral resolution $(\mu \mathrm{m})$ \\
\cline { 2 - 3 } Spectrometer I, VIS & $0.4-0.8$ & 0.2 in 20 bands \\
Spectrometer II, NIR & $1.2-1.5$ & 0.5 in 8 bands \\
Spectrometer III, MIR & $2.0-2.5$ & 0.09 in 64 bands \\
Spectrometer IV, TIR & $8.2-12.7$ & $3.4-5.4$ in 10 bands \\
\hline scan/s 25 & $3 \times 3$ m spatial resolution \\
(1500 m flight altitude) & \multicolumn{2}{c}{12 bit $\times$ pixel, \pm 1 bit } \\
Digital accuracy
\end{tabular}




\subsubsection{Airborne LIDAR Altimeter}

An airborne LiDAR survey (Table 1), with the sensor Hawk Eye II, was used to create a Digital Surface Model (DSM). Forty-two strips were arranged in parallel with overlapping sides of about $20 \%-30 \%[42,53]$. The elevation value for each cell was calculated by averaging all the points included within the cell's boundaries. The final LiDAR DSM grid resolution was $2 \mathrm{~m}$. The airborne survey made between high altitude $(500 \mathrm{~m})$ and low altitude $(250 \mathrm{~m})$ affected the accuracy of the DSM. The accuracy of the DSM (horizontal: $\pm 0.5 \mathrm{~m}$; vertical: $\pm 0.15 \mathrm{~m}$ ) is largely discussed in [51].

\subsubsection{Hyperspectral Airborne Imagery}

The MIVIS sensor is an airborne hyperspectral scanner with 102 spectral bands organized in four spectrometers (Table 2). Two, partially overlapped (about 5\%), images with a spatial ground resolution of $3 \mathrm{~m}$ were geometrically corrected using ground control points identified and collected during the acquisition.

Vegetation and sand cover were detected by selecting a spectral subset of specific hyperspectral ranges ( 20 bands between 0.43 and $0.83 \mu \mathrm{m}$, and 8 bands between 1.15 and $1.55 \mu \mathrm{m}$ ) in order to capture most of the beach-dune targets, as was done in [37,38,54,55].

Atmospheric corrections of MIVIS images were carried out using the ATCOR program based on the MODTRAN radiative transfer model code of small- and wide-field-of-view (FOV) airborne sensors. The atmospheric parameterization of ATCOR- 4 was based on the summer mid-latitude atmosphere, with a maritime aerosol model and a horizontal visibility of $40 \mathrm{~km}$ considering the atmospheric conditions measured during the airborne acquisition. Airborne sensors are much more unstable and sensitive to wind motion; therefore, the scanned data can suffer from distortions related to pitch, yaw, and roll of the aircraft. To cope with these possible sources of error and distortion, mostly on instrumental variables, we used a metafile containing information on the sensor geometry of flight azimuth, zenith of acquisition, and flight altitude.

\subsubsection{Field Measurements}

Fieldwork activities in the study area allowed the gathering of data for the purposes of calibration and correction of atmospheric effects and for validating the image-derived products. In particular, a field campaign conducted synchronously to the airborne overpass provided validation measurements for the vegetation cover retrieval on several sites randomly distributed along the dune system. The Trimble Pro-XRS (Trimble Navigation, Inc., Sunnyvale, CA) global positional system (GPS) led to the identification of ground control points and ten vegetation and sand validation areas, delimited by a frame with $0.5 \mathrm{~m}$ of spatial resolution. These validation areas were appositely selected for the visual estimation of cover percentage and a quick classification of the main vegetation typologies like sand-partially vegetated, shrub and herbaceous vegetation, shrubs, and trees. The field observations dataset was integrated by in situ spectral measurements (Figure 3) with a ViewSpecPRO ${ }^{\circledR}$ ASD (Boulder, CO, USA) instrument [31,35-37]. 

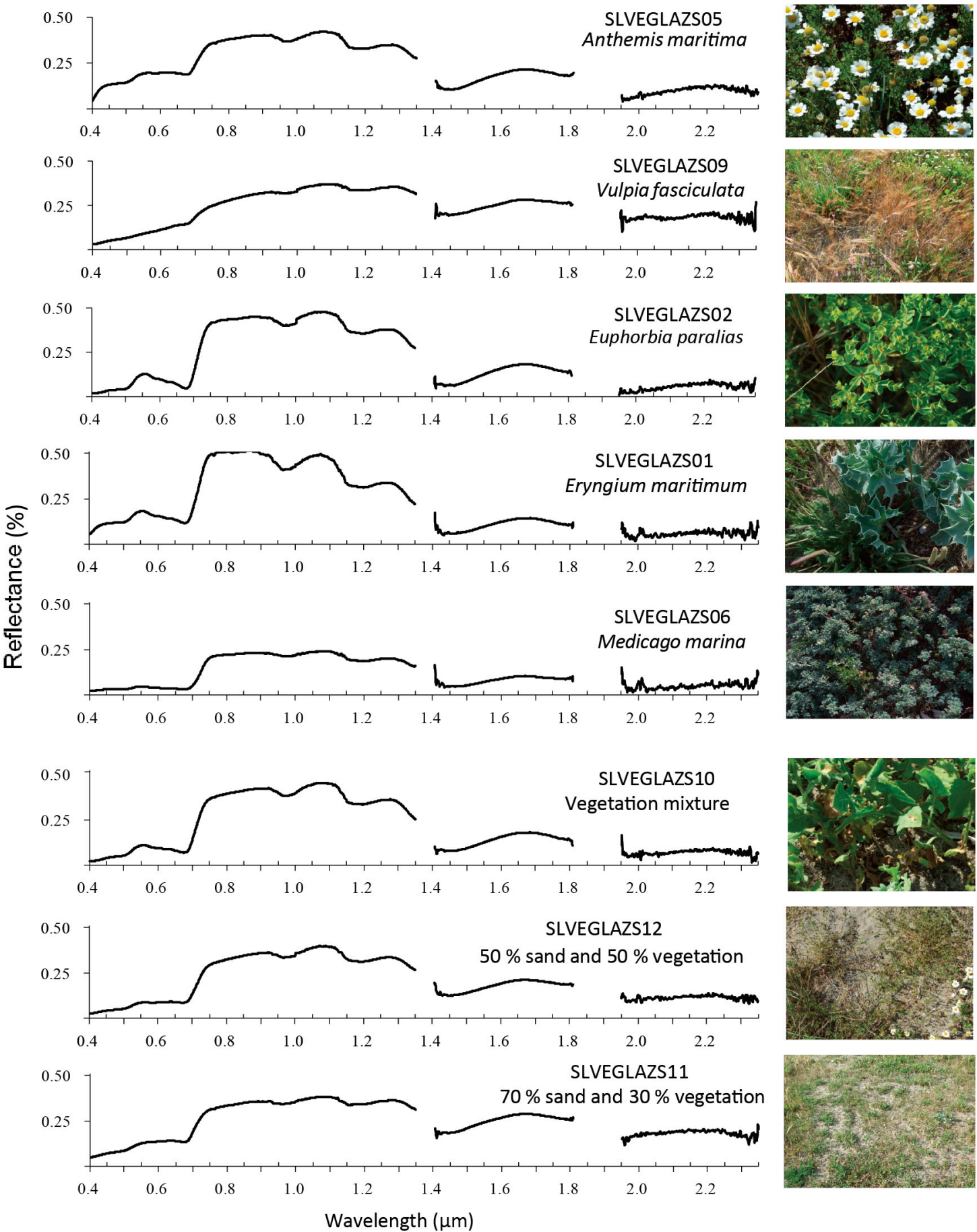

Figure 3. Field spectral library of herbaceous and shrub vegetation typologies collected during the field campaign.

\subsection{Methodology}

The methodology workflow (Figure 4) is based on a three-step analysis approach:

- $\quad$ step 1, a discrete pixel-based analysis to explore the whole system metrics and behavior. The processing is based on the algorithm named 'FHyL (Field spectral libraries, airborne Hyperspectral images and LiDAR altimetry) module 3 ', an algorithm comprising four main modules and two pre-processing steps: Each module differs according to the analyzed coastal 
sphere, i.e., the terrestrial or the aquatic, and according to the sensors' data integration sequence [31,45];

- $\quad$ step 2, a continuous lag-based analysis to explore the relationships between landscape cover and geomorphology;

- $\quad$ step 3, a correlation analysis.

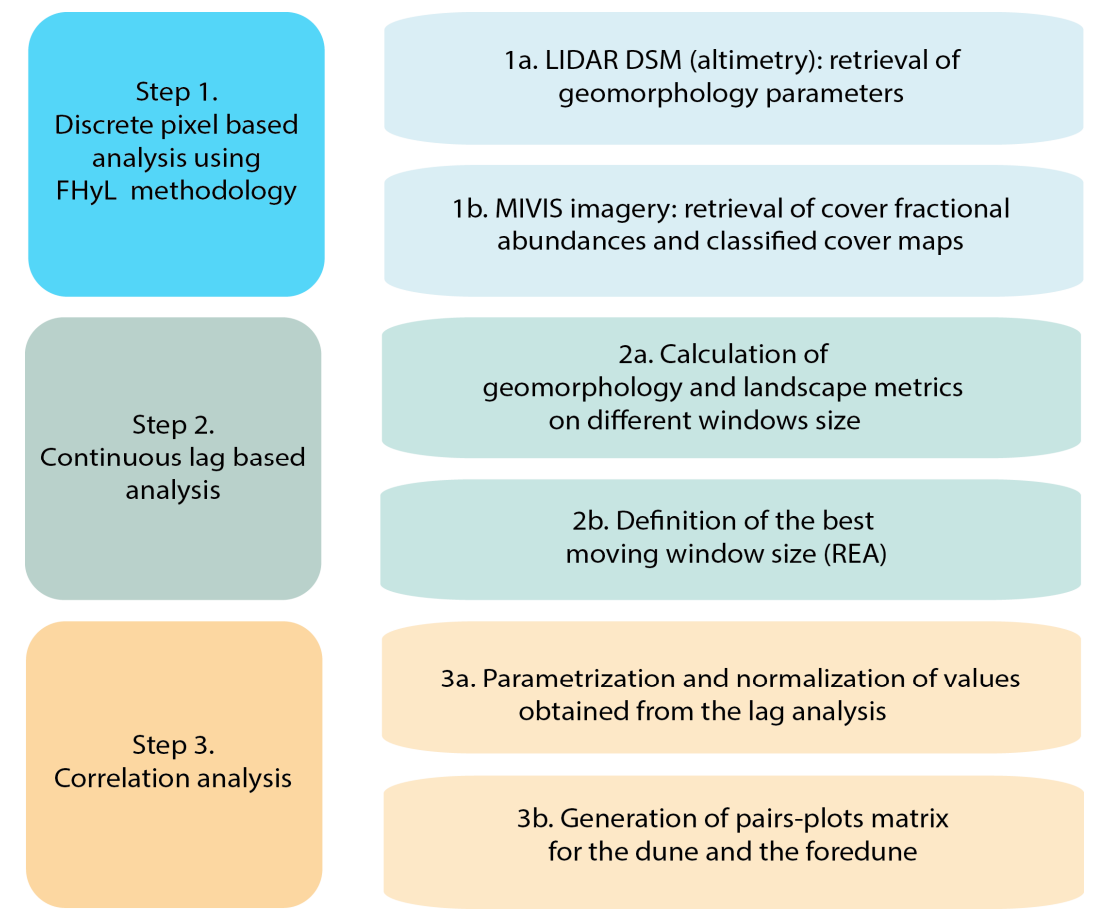

Figure 4. Implementation workflow.

\subsubsection{Step 1: Discrete Pixel-based Analysis}

The LiDAR DSM (step 1a in Figure 4) is used to derive basic geomorphological parameters for the beach-dune system, the foredune, and the hind dune. The north-south morphological characterization was obtained by calculating, through a GIS-based approach (Figure 5), specific attributes from the LiDAR DSM: slope, dune foots, dune crest, shoreline, width for the beach, the foredune, and the hind dune (Table 3).

Sinuosity was calculated with the following equation:

$$
s=l / L
$$

where $l$ is the along-foot line length and $L$ is the straight-foot line distance between the starting and ending points [35].

In addition, the profile underlying the surface, a proxy for the sediment volume of the dune, was calculated with the following equation:

$$
S=\int_{L}^{0} h d L / L,
$$

where $S$ is the surface of each profile derived from $L$, the horizontal length of the profile, and $h$, the elevation along the profile. The strategy for the profiles underlying the surface follows the greatest area under their longitudinal profile divided by their length (average elevation) [56]. 


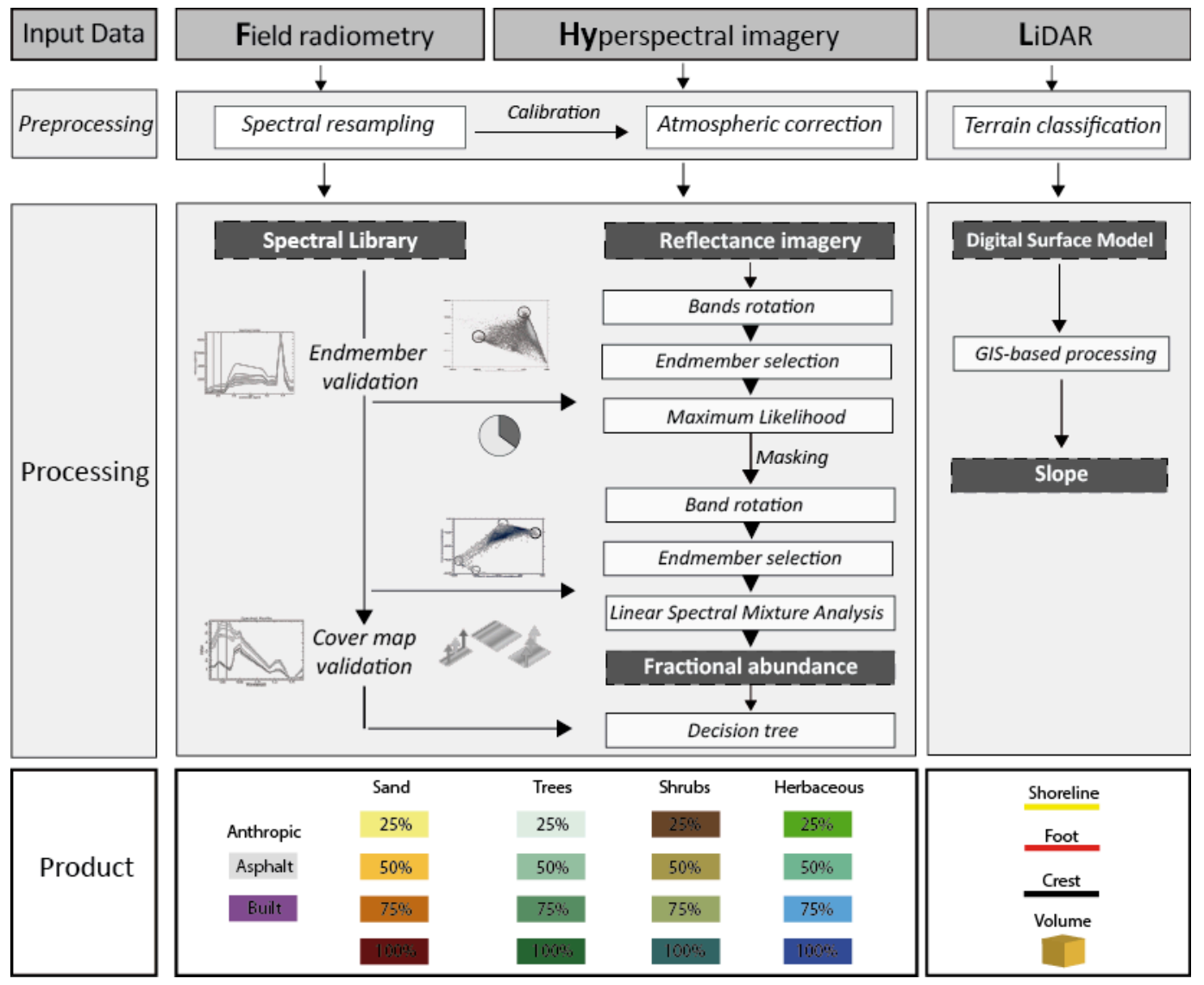

Figure 5. Description of step 1 in Figure 4: The processing algorithm used is named 'Field, Hyperspectral and LiDAR (FHyL) module $3^{\prime}$.

Table 3. Parameters and products generated for the discrete pixel-based analysis.

\begin{tabular}{|c|c|}
\hline Primary Parameter (units) & How to Calculate \\
\hline Slope (deg) & Maximum change in elevation over the distance between the cell and its eight neighbors \\
\hline Crest $(\mathrm{m})$ & Maximum of dune ridge elevation \\
\hline Foot $(\mathrm{m})$ & Foot results from defining a threshold on the slope \\
\hline Width (m) & $\begin{array}{l}\text { By using the horizontal plane referred to mean sea level for the following distances: } \\
\text { from the shoreline to the foredune foot (beach) } \\
\text { from the foredune foot to the crest (foredune) } \\
\text { from the crest to the hind dune foot (hind dune) } \\
\text { from the foredune foot to the hind dune foot (dune) }\end{array}$ \\
\hline Profile underlying the surface $\left(\mathrm{m}^{2}\right)$ & $\begin{array}{l}\text { The signed area, bounded by the elevation profile of each transect, corresponds to the } \\
\text { integral of the elevation profile. Each profile has been separately calculated along the } \\
\text { transect for the beach, foredune, and hind dune }\end{array}$ \\
\hline Fractional Abundances (\%) & $\begin{array}{c}\text { Combining a maximum likelihood classification (MLL) and a linear spectral mixing } \\
\text { analysis (LSMA) }\end{array}$ \\
\hline Detailed cover map (classified map) & Using a decision tree to apply a threshold on fractional abundances (fraction $>60 \%$ ) \\
\hline
\end{tabular}

The hyperspectral data are used to characterize the spatial distribution of the vegetation and sand; thus, from the MIVIS imagery (step $\mathbf{1 b}$ in Figure 4), cover fraction abundances for the vegetated and non-vegetated areas (i.e., sand, herbaceous, shrubs, trees, road, and anthropic abundance fractions) are retrieved by applying linear spectral mixture analysis (LSMA) with the field measurements $[31,35,45,57]$. The LSMA allows for modelling of the total reflectance of each pixel as a linear combination of spectrally pure reflectance signals of different targets called endmembers [58]. In Figure 5, the processing of the hyperspectral data is graphically represented.

To cluster the pixel main reflectance variance, principal component analysis (PCA) is used to operate a rotation of the spectral bands, and at the apexes of the 2-d image-derived scatterplots, a cluster 
of pixels (endmembers), representing the vegetated and the non-vegetated (sand and substrates) cover, are selected $[15,59]$.

The two mean spectral signatures (vegetation and sand) provided the training sets for running the maximum likelihood classification (MLL) of the two images. This classification works by assigning each pixel to the class for which the conditional probability is greater, defined as the probability that a pixel selected from the scene belongs to a particular class. From the MLL, the mask of vegetated and non-vegetated classes is obtained.

The LSMA was then applied to the two subsets of the vegetated and non-vegetated pixels of the dunes obtained by the MLL classification, allowing the identification of six products, the fractional cover abundance of three substrate typologies, i.e., anthropic, sand, and asphalt, and three vegetation typologies, i.e., herbaceous, shrubs, and trees (Table 3). The root-mean-square error of the fractional cover abundances indicated the accuracy of the mathematical results obtained by inversion of the LSMA (unmixing) for each pixel for each band [60,61], and it was mostly below 0.5, allowing reliability of the inversion. Through the Pearson correlation between the six endmember spectral signatures collected from the vegetated and non-vegetated pixel subsets and the field spectral library collected during the validation campaign, the thresholds for the decision tree classification of the fractional cover abundance to generate a classified cover map are determined (Table 3). The accuracy estimation of the product is also estimated by comparing the unmixing errors in the overlapping areas of the two images [36] and the final map with the field observations [31].

\subsubsection{Step 2: Continuous Lag-Based Analysis}

Parameters identified in Table 3 along with additional landscape metrics derived from the application of the tool Fragstat [62] are summarized in Table 4 (step 2a in Figure 4). The landscape metric was used to quantitatively analyze the dune ridge cover composition and the level of spatial heterogeneity in terms of cover typologies, aggregation, and contiguity. A selection of Fragstat indexes related to landscape level were used to describe the landscape heterogeneity, and the overall landscape pattern and a selection of indexes related to patch metrics were used in terms of aggregation metrics and as a proxy for the landscape texture and grain. The class level, useful to measure the fragmentation at the landscape level, was derived from the patch metrics in order to reduce the redundancy and the autocorrelation of the analysis.

Table 4. Parameters generated for the continuous analysis (lag-based).

\begin{tabular}{|c|c|}
\hline Primary Parameter (unit) & How to Calculate (in the Moving Window) \\
\hline Elevation (m) & As average value \\
\hline Sinuosity & As average value of the crest and foot lines \\
\hline Width $\left(\mathrm{m}^{2}\right)$ & As average value \\
\hline Profile underlying surface & As average value of the elevation profiles' integrals \\
\hline Cover percentage $(\%)$ & Cover percentage referred to the window extent \\
\hline Edge Density (ED) & $\begin{array}{l}\text { Edge density of the cover patches. It standardizes the edge to a per-unit-area } \\
\text { basis that facilitates comparisons among landscapes of varying size. }\end{array}$ \\
\hline Landscape Shape Index (LSI) & $\begin{array}{l}\text { Measure of the perimeter-to-area ratio for the whole landscape. The minimum } \\
\text { value of LSI is always equal to } 1 \text { when the landscape consists of a single patch. }\end{array}$ \\
\hline Mean fractal dimension & Fractal dimension of each patch \\
\hline Aggregation index & $\begin{array}{l}\text { The ratio of the observed number of like adjacencies to the maximum possible } \\
\text { number of like adjacencies given the proportion of the landscape comprising each } \\
\text { patch type, given as a percentage. }\end{array}$ \\
\hline Effective mesh size & $\begin{array}{l}\text { Mesh size refers to the cumulative patch area distribution and is the size of the } \\
\text { patches when the corresponding patch type is subdivided into } S \text { patches, where } S \\
\text { is the value of the splitting index. }\end{array}$ \\
\hline Patch Cohesion Index (PCI) & $\begin{array}{l}\text { Measures of the connectivity of patch typologies. It takes into account the number } \\
\text { of patches, the surface, and its perimeter }\end{array}$ \\
\hline
\end{tabular}

The analysis between the vegetation and topographic variables, thanks to the typology of the dataset, is set to run on a continuous basis considering the system as a single dune ridge, in order to 
select the best size of the moving window corresponding to the real elementary area (REA) (step $\mathbf{2 b}$ in Figure 4).

The dune crest line was used to operate a line simplification to reduce the transect overlay (Figure 6, first section).

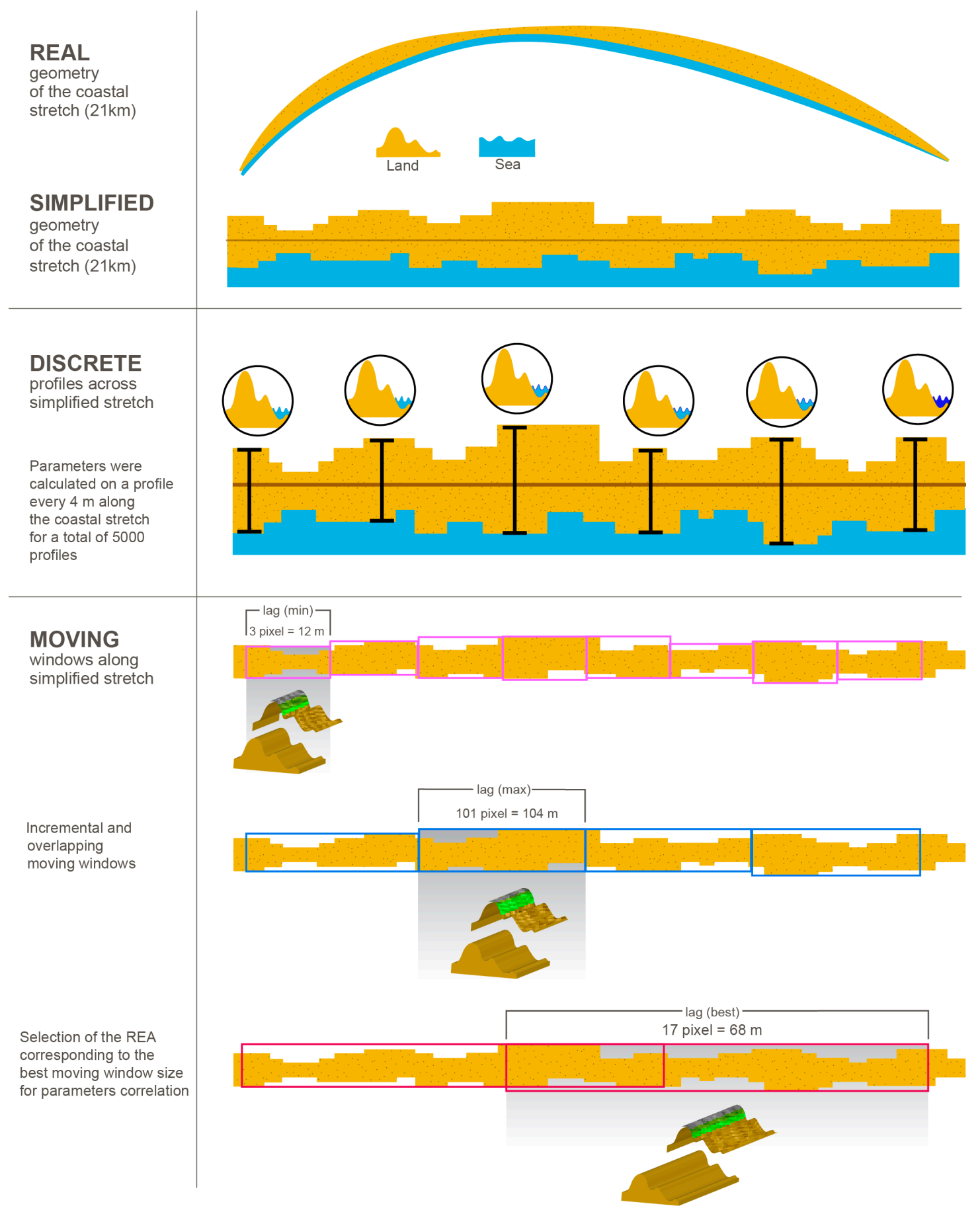

Figure 6. Graphical explanation of step 2 in Figure 4. The first section shows how the convex coastal stretch geometry is treated to obtain the simplified geometry for the continuous analysis. The second section shows how the 5000 transects are distributed. The third section shows how the moving windows size varies from $12 \mathrm{~m}=\operatorname{lag} 3$ to $404 \mathrm{~m}=\operatorname{lag} 101$, and the real elementary area (REA) of $68 \mathrm{~m}$. 
After the line simplification, the crest line was used as a baseline to generate approximately 5000 orthogonal transects running from the north to south of the considered coastal stretch, which extends approximately $21 \mathrm{~km}$ (Figure 6, second section).

The transect width of $4 \mathrm{~m}$ (lag1) is assumed as the unit for testing different moving window sizes, $12 \mathrm{~m}$ (lag3) being the smallest and $404 \mathrm{~m}$ (lag101) the largest.

All the parameters and metrics are calculated shifting the moving window with a $4 \mathrm{~m}$ step (i.e., 1 transect) along the beach-dune system. Parameters calculated in each moving window refer to the central transect of the window itself. Those parameters whose values are pixel-based are calculated as the average within the window area. By evaluating the moving window size that could best correlate the majority of selected parameters (Table 4 ), the procedure resulted in the selection of a moving window length of $68 \mathrm{~m}$ corresponding to the REA (Figure 6 third section).

\subsubsection{Step 3: Correlation Analysis between Landform and Landscape Metrics}

The overall set of parameters and metrics considered for the correlation analysis (step 3 in Figure 4) are shown in Table 4.

Values obtained from the lag analysis were normalized (step 3a in Figure 4) to be plotted in pairs for the dune and the foredune, and two correlation matrices were derived (step $\mathbf{3 b}$ in Figure 4). A pair plot is also known as a scatterplot, in which one variable is matched with another variable's value. The matrix of pair plots showing correlations among pairs of variables is a square table where all the variable correlations are reported. Typically, each variable distribution is available on the diagonal of the matrix, and the scatterplots of each pair of variables are drawn on the left part of the figure corresponding to the Pearson correlation value displayed on the right. Correlations were analyzed with regard to their sign, i.e., positive or negative, and their magnitude, and interpreted in relation to dune vegetation and sediment cover.

\section{Results}

Results are described in order to first provide a description of the landforms and the landscape properties of the beach-dune system from both the discrete pixel-based and the continuous lag-based analyses (step 1 and step 2 and Figure 4, respectively). These results highlighted relevant differences between the whole dune and the foredune and provided support for the description of the correlation results moving from north to south (step 3 and Figure 4).

\subsection{Step 1 and Step 2: Dune Morphology}

Analyzing the morphological parameters along the coastal stretch (i.e., discrete domain analysis, Table 5), it can be observed that the elevation and foredune width in the southern part are almost double those in the northern area. The elevation of the emerged beach and dune crest increases southward, whereas the foredune foot has an elevation of about $2 \mathrm{~m}$, although inconsistent behavior mostly occurs in the southern part of the coastal stretch. The foredune foot sinuosity shows values ranging from 0.96 to 0.86 moving from north to south. The dune crest sinuosity shows values ranging from 0.91 to 0.77 even if influenced by the main coastal road running on the crest.

Table 5. Beach-dune system morphometry.

\begin{tabular}{cccccc}
\hline $\begin{array}{c}\text { Distance along } \\
\text { Stretch }(\mathbf{k m})\end{array}$ & $\begin{array}{c}\text { Foredune } \\
\text { Width }(\mathbf{m})\end{array}$ & $\begin{array}{c}\text { Hind dune } \\
\text { Width }(\mathbf{m})\end{array}$ & $\begin{array}{c}\text { Beach } \\
\text { Width }(\mathbf{m})\end{array}$ & $\begin{array}{c}\text { Profile Underlying } \\
\left.\text { the Surface } \mathbf{( m}^{\mathbf{2}}\right)\end{array}$ & Elevation $(\mathbf{m})$ \\
\hline 1.5 & 25.4 & 100 & 29.7 & 581.6 & 4.1 \\
4.5 & 36.0 & 89.5 & 12.7 & 868.0 & 4.2 \\
7.5 & 21.2 & 28 & 42.4 & 410.5 & 5.0 \\
10.5 & 41.5 & 70.6 & 23.1 & 1313.1 & 4.9 \\
13.5 & 86.7 & 27.5 & 26.8 & 9143.5 & 7.7 \\
16.5 & 36.0 & 203.7 & 26.1 & 1111.5 & 5.3 \\
19.5 & 98.5 & 124.6 & 30.7 & $12,492.4$ & 11.4 \\
\hline
\end{tabular}


Observing the same parameters by using the continuous analysis, these north-south trends are the results of the values increasing mostly linear, and three or more sub-trends are detectable (Figure 7).
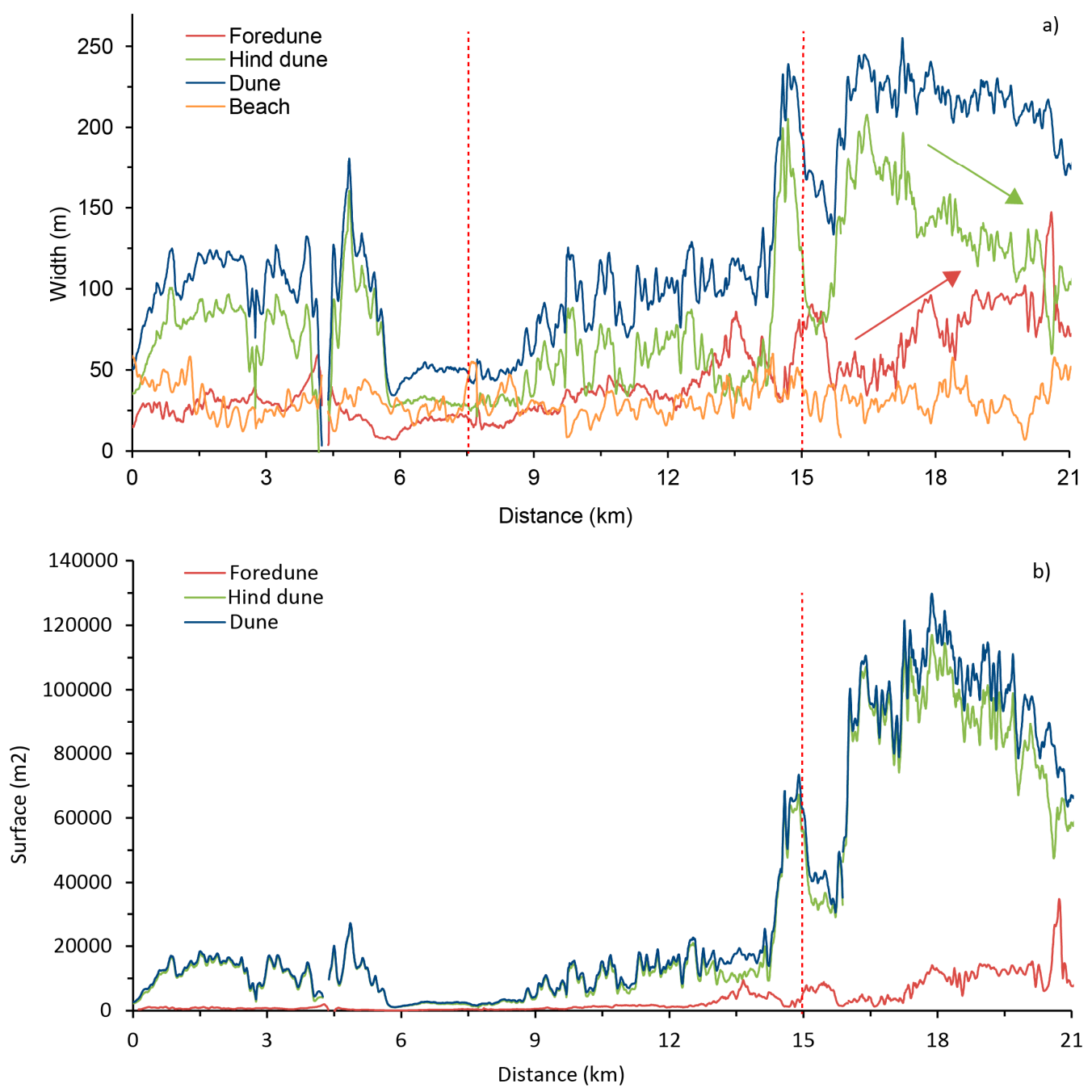

Figure 7. Description of the morphological main behavior moving from north to south: (a) Width vs. distance; (b) profile underlying the surface vs. distance. Parameters refer to the $68 \mathrm{~m}$ moving window.

The width of the dune (both foredune and hind dune sides) and the hind dune (Figure 7a) have a similar behavior-differing for the magnitude of values-in which three main trends can be detected. The foredune, in general, shows lower and less scattering values, except for the southern part of the stretch. Southward, an increasing width in the foredune and the opposite trend of decreasing width in the hind dune are observed. It is also worth observing that the dune width shows an abrupt change at approximately $15 \mathrm{~km}$ in correspondence with the appearance of the anthropic cover (buildings). The emerged beach has its own behavior represented by a very scattered trend but with a lower variability compared to the dune, the foredune, and the hind dune.

Due to the increasing elevation and width of the dune moving from north to south, the values of the profiles underlying the surface are always higher than those of the foredune (Figure $7 \mathrm{~b}$ ). In particular, from $15 \mathrm{~km}$, the foredune significantly increases its size up to $5000 \mathrm{~m}^{2}$, and the dune and the hind dune experience a sharp increase, reaching 100,000 $\mathrm{m}^{2}$. 


\subsection{Step 1 and Step 2: Dune Cover Patterns}

The cover map describes the presence of vegetation compositions that include arboreal formations across the dune system. To better illustrate the results of the cover distribution, the results are coupled in a single figure (Figure 8).
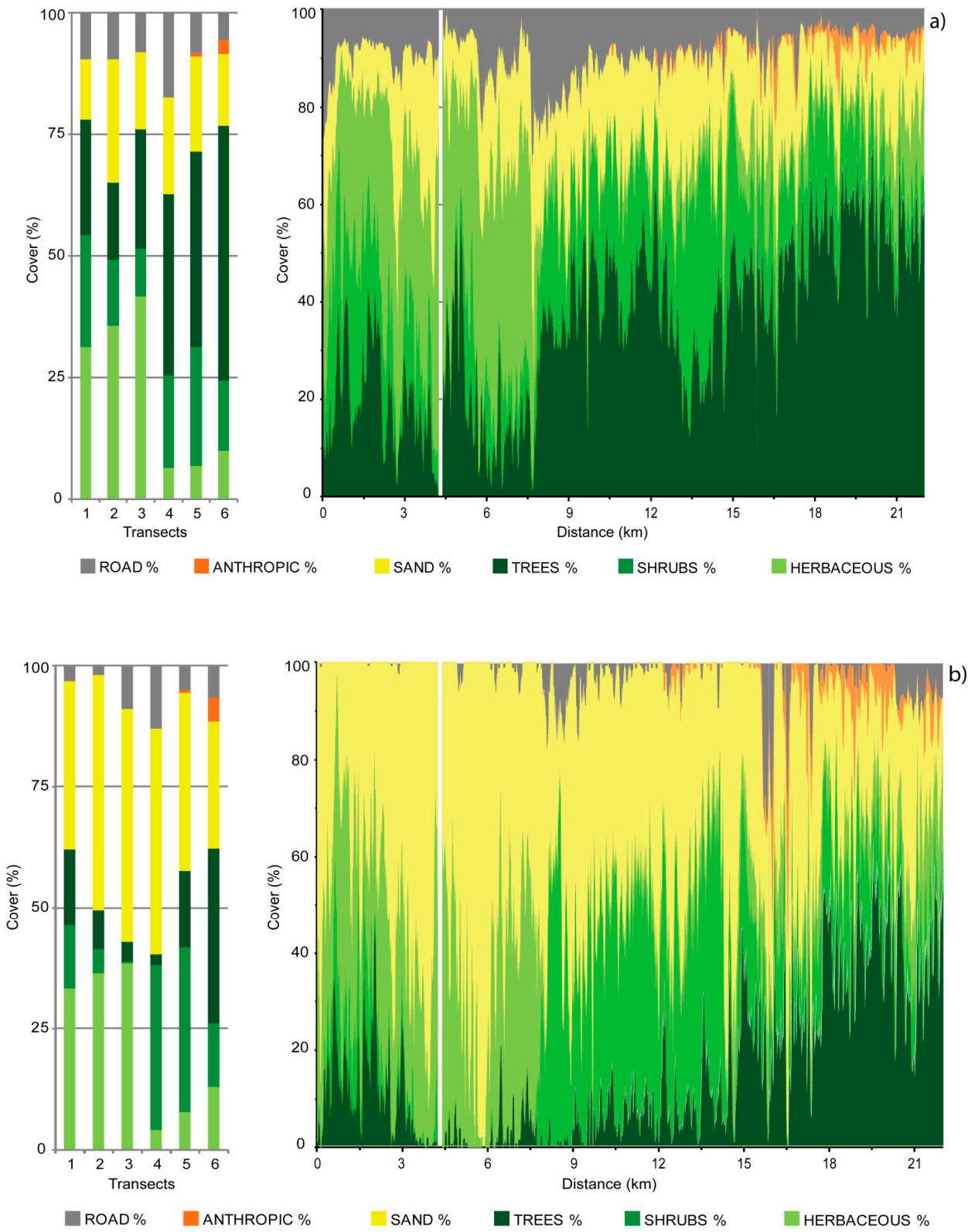

Figure 8. Cover typology abundance in six transects (left side) and along the stretch (right side) for (a) the dune and (b) the foredune.

From the discrete analysis of the dune cover typologies on profiles, it is possible to observe how the cover typology percentage varies along the stretch. In the discrete analysis, sand and herbaceous-shrubs are the two prevalent cover typologies of the foredune (Figure 8a) with a small presence of anthropic cover: $43 \%$ sand, $17 \%$ herbaceous, $18 \%$ shrubs, $17 \%$ tree, and $4 \%$ anthropic cover.

When the entire dune is considered (Figure $8 \mathrm{~b}$ ), herbaceous (18\%) and trees $(36 \%)$ are more abundant, and $10 \%$ of anthropic cover is mostly present in the southern area. Trees are mostly present in the southern part of the stretch, but they can also be found in other zones, even if with lower cover percentage values, especially in the foredune central part where shrubs are dominant. The cover 
classification compared to the other available classifications of the same area and with our field data is reliable in terms of accuracy [21].

\subsection{Step 3: Dune Landforms and Landscape Correlations}

Correlation matrices for the dune (d) and the foredune (fd) are made by forty variables matched with each other. These variables are those reported in Table 4 and calculated within REA (the moving window of $68 \mathrm{~m}$ ). In Figure 9, a selection of the most correlated variables (r-values $\geq 0.6$ and r-values $\leq-0.6$ ) is reported, and the whole matrices of 160 pair plots obtained are available in Supplementary Materials $(\mathrm{S} 1, \mathrm{~S} 2)$.
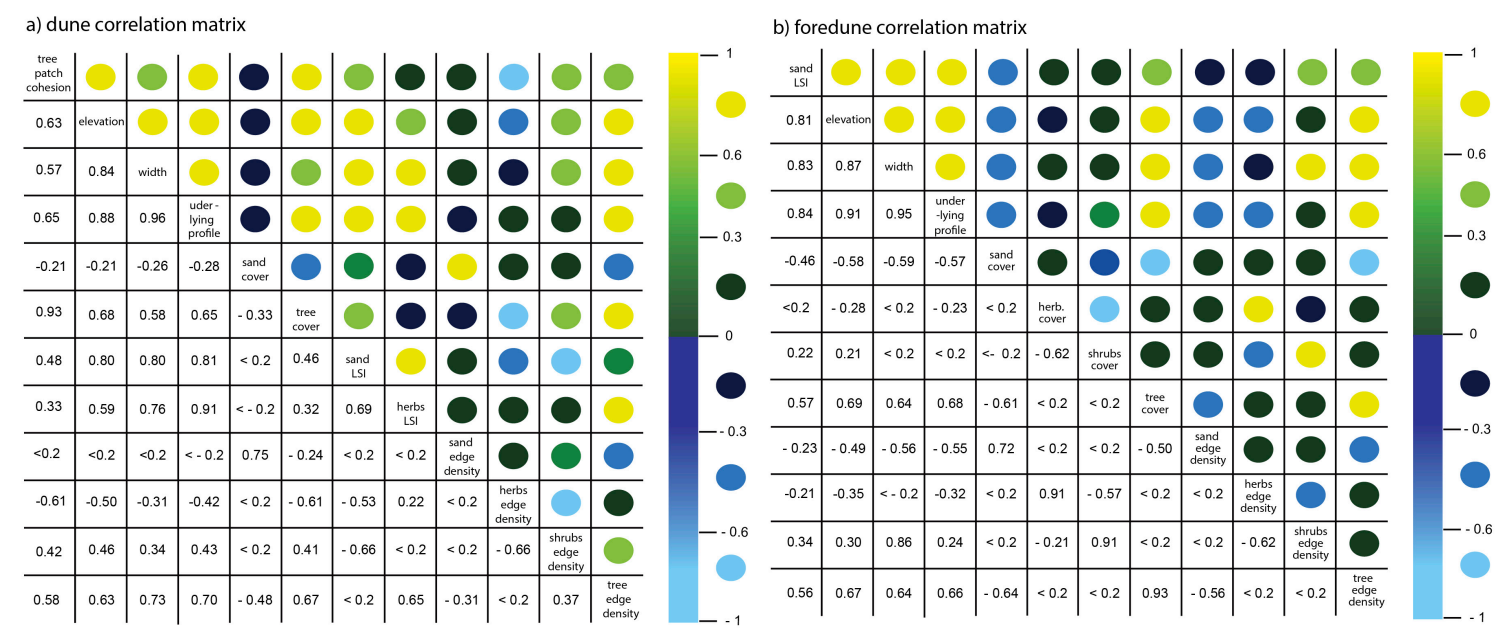

Figure 9. Correlation matrices of selected geomorphology and landscape metrics for: (a) dune and (b) foredune. In the matrices, low correlation is indicated by green ( $\mathrm{r}$ up to 0.3 ) and blue dots ( $\mathrm{r}$ up to -0.3 ); medium correlation is indicated by light green $(0.3 \leq \mathrm{r} \leq 0.6)$ and light blue $(-0.3 \leq \mathrm{r} \leq-0.6)$ dots; high correlation is indicated by yellow $(0.6 \leq \mathrm{r} \leq 1)$ and very light blue $(-0.6 \leq \mathrm{r} \leq-1)$ dots.

The land cover spatial patterns were investigated in terms of fragmentation considering the landscape indexes. The number of patches of all vegetation typologies was higher in the southern part but not related to a specific typology. A significant correlation was not between sand cover and the elevation and slope, as generally expected in a dune system, but between the patterns and fragmentation of the sand and vegetation, especially for the edge density of patches and the landscape shape index.

When considering the dune (foredune and hind dune together) or only the foredune, the sand edge density (ED) trend is the same and usually opposite to that of the herbaceous typology. In particular, herbaceous and shrub ED values are inversely correlated as (fd) $r=-0.62$ and (d) $r=-0.66$ (Figure 9), meaning that the two vegetation typologies do not follow a regular north-south gradient. At $7.5 \mathrm{~km}$, a significant change in foredune ED values is observed in correspondence to a change in the foredune width trend. Around $15 \mathrm{~km}$, the foredune width increases and the shrub patches appear numerous and dense (Figure 7).

Considering that the patch ED index is landscape scale-independent, these trends suggest that the increased width and elevation can favor a more structured vegetation presence. The ED values of trees follow the shrubs until $7.5 \mathrm{~km}$, and then overlap the herbaceous ones until $15 \mathrm{~km}$. It is worth noting that the anthropic cover typology appears along the dune ridge around $15 \mathrm{~km}$, and moving south, it is increasingly present in the foredune zone (Figure 10).

The sand landscape shape index (LSI) of the foredunes varies linearly with the elevation ( $\mathrm{fd}$ ) $\mathrm{r}=+0.81$ (Figure 11a) and the width ( $\mathrm{fd}$ ) $\mathrm{r}=+0.83$ (Figure 11b); therefore, it has a strong positive correlation with the profiles underlying the surface $(\mathrm{fd}) \mathrm{r}=+0.84$ and $(\mathrm{d}) \mathrm{r}=+0.71$. The $\mathrm{fd}$ sand LSI, a simple measure of class aggregation, is highly positively correlated with the $\mathrm{fd}$ shrub LSI, $(\mathrm{fd}) \mathrm{r}=+0.85$, 
and with all the other $\mathrm{fd}$ cover typologies LSI (herbaceous $(\mathrm{fd}) \mathrm{r}=0.74$, trees $(\mathrm{fd}) \mathrm{r}=0.77$ ). These values represent the typical correlation model of disaggregated landscapes where the length of the patch edge within the landscape increases parallel to the size and elevation of the dune. In practice, the LSI increases for all the cover typologies moving south in the dune ridge, meaning that the patches increase in size and disaggregation, including sand cover [13].

a)

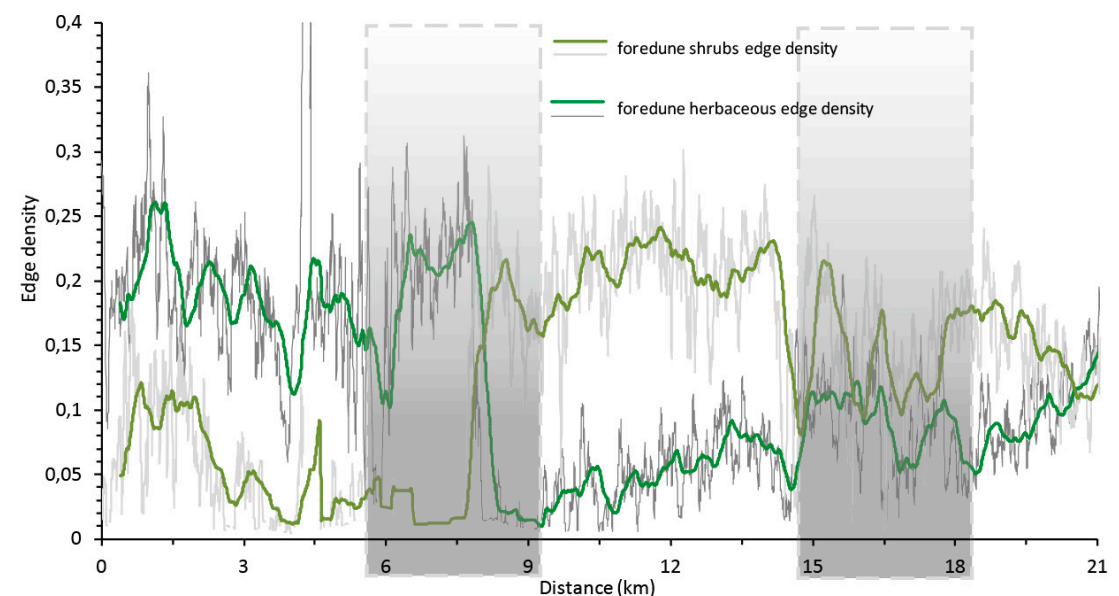

b)

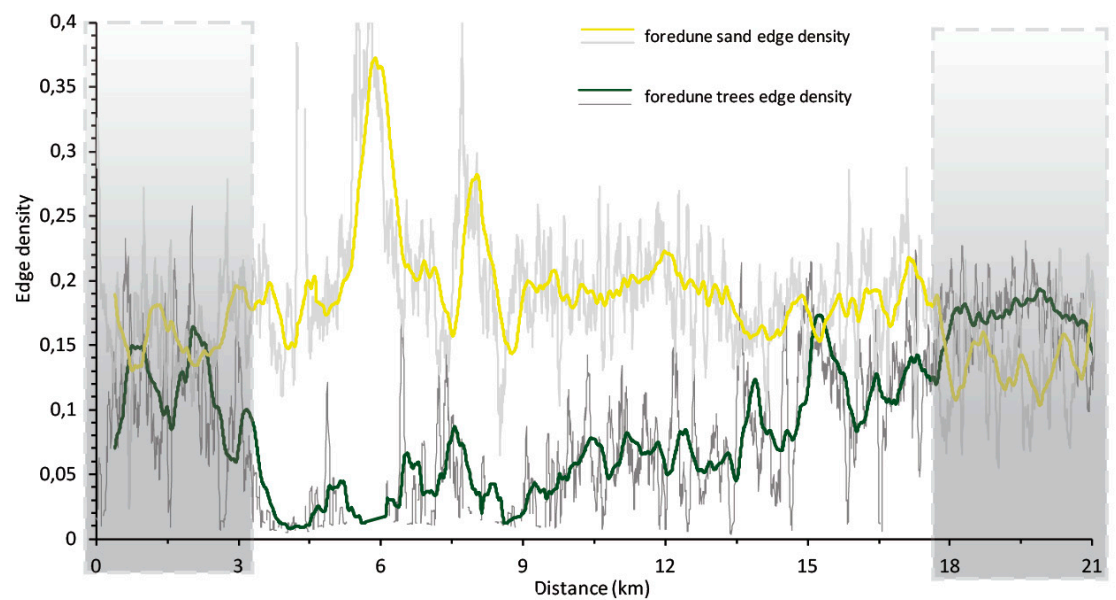

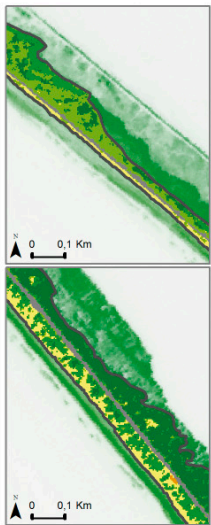

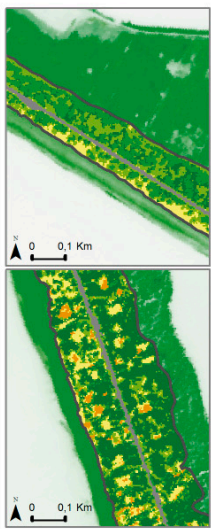

Figure 10. (a) Foredune herbaceous and shrubs edge density values: Two main changes in trend are detectable at 7.5 and $14.5 \mathrm{~km}$. (b) Foredune sand and trees edge density values: Reversed trend between 0 and $2.5 \mathrm{~km}$ and after $15 \mathrm{~km}$. Gray lines represent all the data points, and the colored bold lines, used to enhance the graphical view of each trend, are the moving averages of data points (average of 100 data points interval). On the right side, the miniatures show the dune cover map corresponding to the highlighted grey windows in the graphs (note that the orange color is the anthropic cover class not shown in the foredune edge density (ED) trends).

It is not possible to define a critical threshold [32,35] where, for example, small changes in the sand LSI in values are related to abrupt changes in the morphology, determining changes in the environmental patterns. The foredune sand LSI is, in fact, also inversely related for long parts of the coast, with the sand cover percentage that shows higher values in the northern part of the stretch, while the LSI has higher values in the southern part (Figure 12). This means that in the south, the sand cover is both reduced and discontinuous.

From the analysis of the landscape aggregation, the foredune patch cohesion (PC) shows significant increases after $\mathrm{km} \mathrm{7.5,} \mathrm{where} \mathrm{sharp} \mathrm{changes} \mathrm{in} \mathrm{the} \mathrm{trees} \mathrm{and} \mathrm{herbaceous} \mathrm{trends} \mathrm{can} \mathrm{be} \mathrm{highlighted.}$ Similarly, the aggregation index (PC) of the same classes (trees and herbaceous) has very discontinuous 
behavior until $10 \mathrm{~km}$, after which homogenous increasing trends can be observed for both the dune and the foredune.
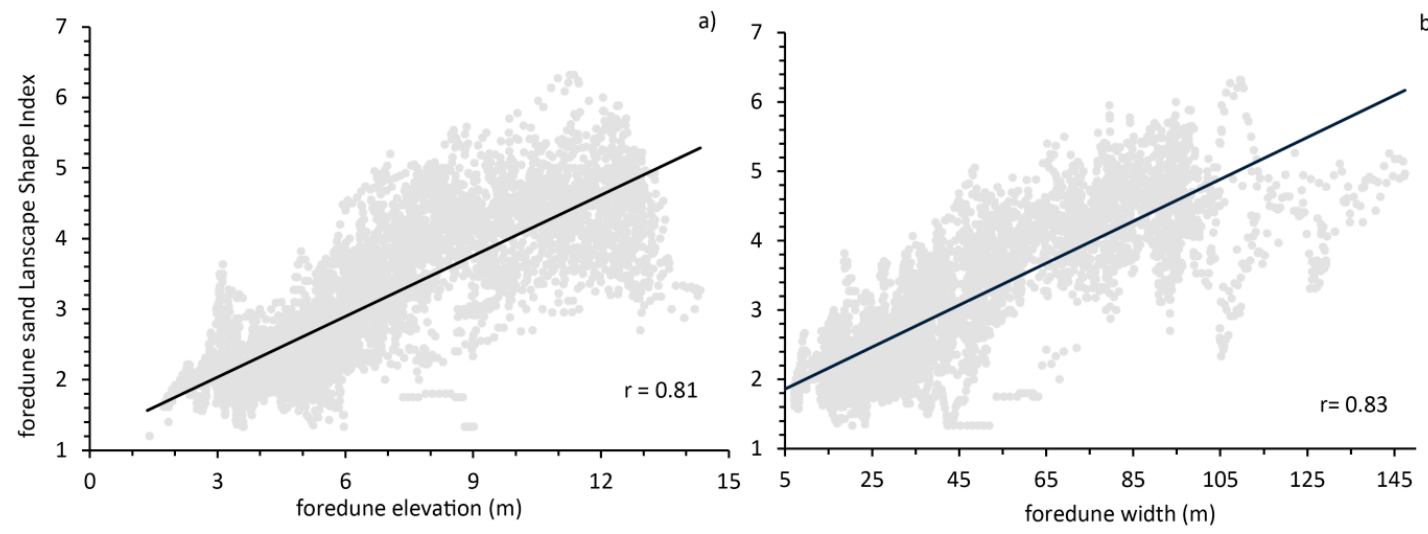

Figure 11. Foredune sand landscape shape index vs. (a) foredune elevation and (b) foredune width.

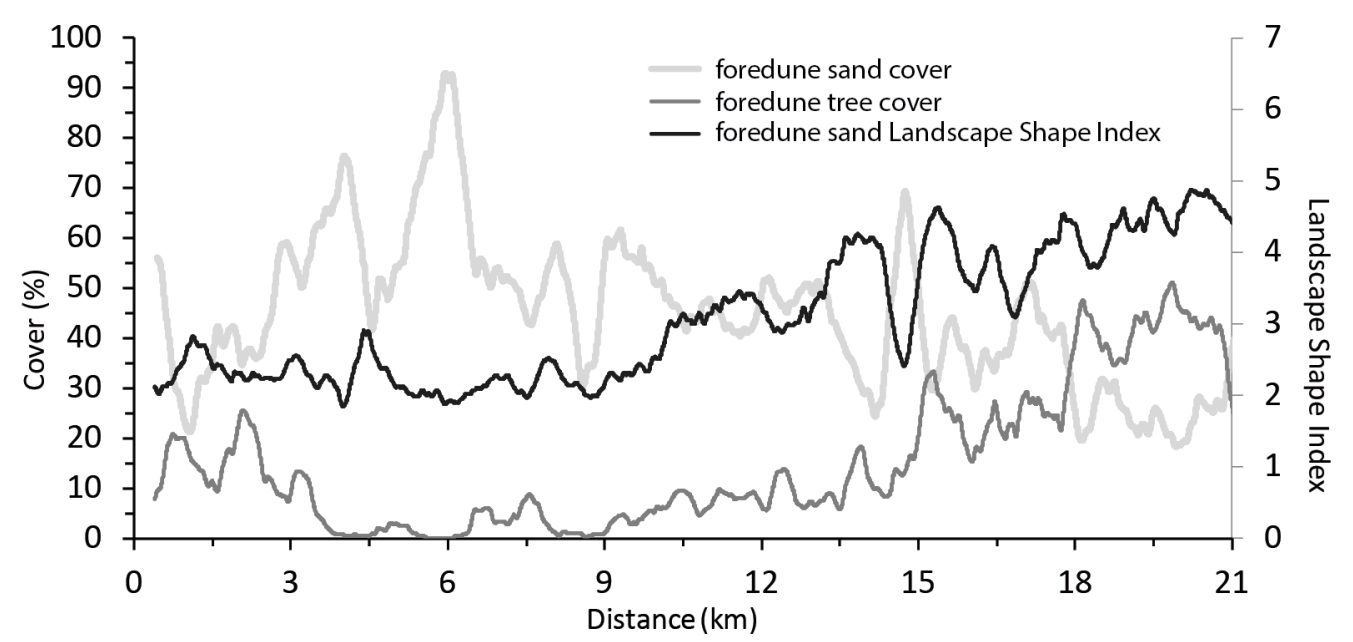

Figure 12. The foredune sand cover (light grey line) has higher values in the northern part of the stretch, while the landscape shape index (black line) has higher values in the south. A major contribution to these behaviors is due to the growing cover percentage of trees (dark grey line) moving from north to south. Values are reported as moving averages of data points (average of 100 data points interval).

Sinuosity peaks occur with a non-continuous trend moving from north to south (Figure 13). The anthropic cover of the foredune is very low until $7 \mathrm{~km}$ and significantly increases after $15 \mathrm{~km}$. The highest values are between 15 and $17 \mathrm{~km}$, where sinuosity values decrease. 


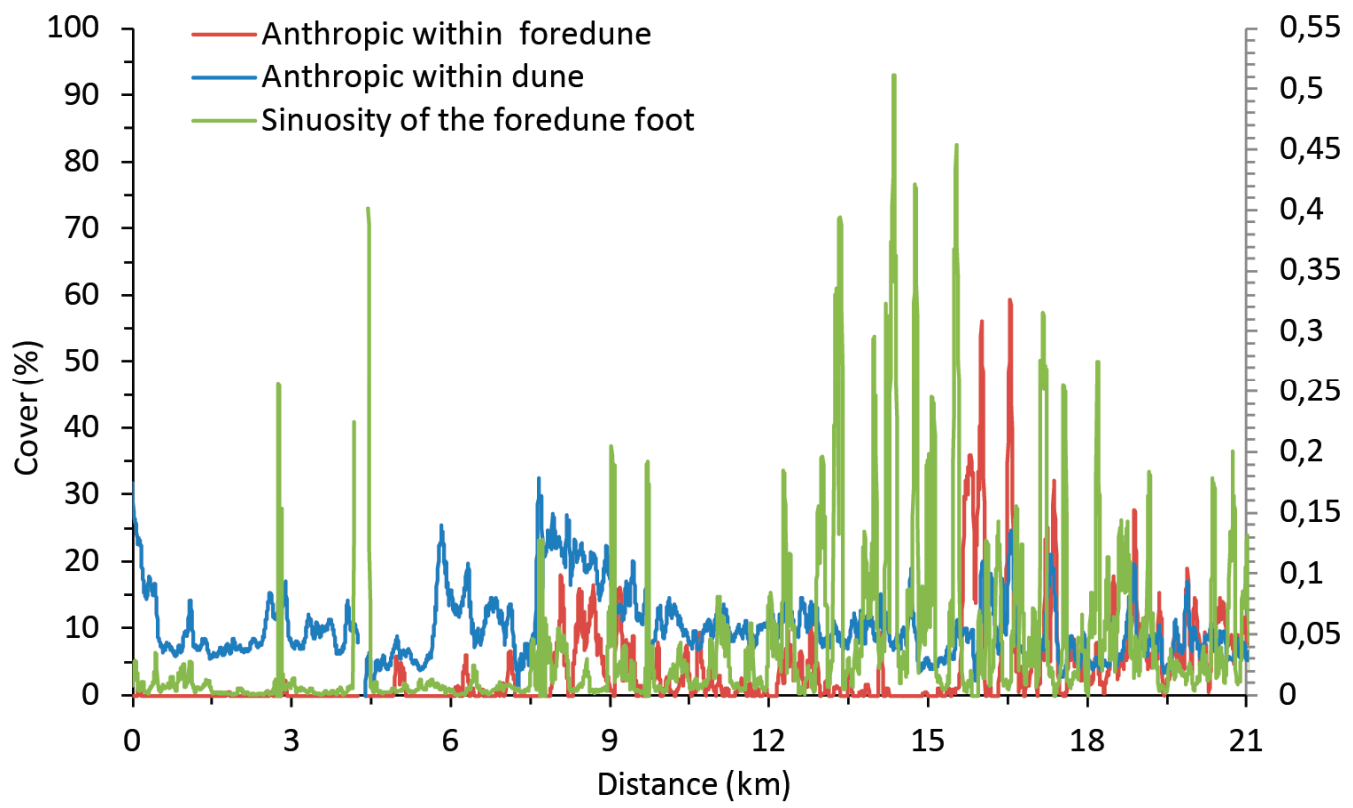

Figure 13. Foredune foot sinuosity (green) and dune anthropic cover (blue). While the anthropic cover is present all over the dune stretch, the foredune (red) shows an increasing presence moving south from $7 \mathrm{~km}$ onward.

\section{Discussion}

The unique contribution of remote sensing to the study is provided by the novelty of the processing approach that combines the hyperspectral data with parameters obtained from LiDAR. It is rare having a classification of trees, herbaceous, and shrubs classes, and the study proves that the integration of hyperspectral airborne and field sensors via spectral mixture analyses can support this kind of classification. By inspecting vegetation and sand cover obtained by processing hyperspectral data and the LiDAR DSM, it is possible to understand how fragmented the sand landscape is when there is also presence of vegetation and anthropic cover, and how topography is related to the vegetation and the sand distribution.

Considering the results obtained for morphological characterization of the dune system [63], the foredune is a highly dynamic environment reactive to external drivers, both natural- (i.e., marineand weather-related) and human-driven. Unless marine forces favor the southern portion of the stretch in terms of elevation and width, the trees, herbaceous, and shrub cover are directly and inversely related to the dune and foredune width and the profile underlying the surface, but with variable magnitude. It is already known that the limited variation of the foot dune elevation is influenced by the action of waves that, due to winter storms, periodically erode the dunes where the beach width is limited and the system is more vulnerable [64]. Beach width has the primary role in protecting the backshore habitats from the direct impact of surges during storms, but the effect of aerosols on vegetation is highly variable depending on vegetation type and assemblages (Figure 8).

The intersections of a variety of ecomorphological parameters have largely been used to extend and extrapolate vegetation presence and variability within the morphological dunes $[10,16,64,65]$. Coastal dune system classification traditionally uses orthogonal analyses of the ridges moving from the foot of the hind dune (lee side) to the shoreline. Here, thanks to the spatial continuity of data offered by the hyperspectral and LiDAR acquisition, there is a mixture of orthogonal transects and moving windows that enables the derivation of both discrete and continuous metrics describing the actual ecogeomorphological relations of the dune environment (perpendicular and parallel to the dune ridge).

The width profile underlying the surface and elevation show many correlations with the cover percentages and landscape indexes, even if the sand cover percentage does not follow the behavior observed for the profile underlying the surface moving north to south (Figure 7, Figure 12). 
As an unexpected result, we observed a weak linear correlation for the sand cover percentage with the patchiness and the fragmentation of the landscape.

Several studies have demonstrated the effect of vegetation density on the width of the sedimentation for time periods of weeks $[11,13]$, but in the present study, the sand cover LSI is positively correlated with the morphological parameters and with the trees, shrub, and herbaceous LSI, meaning double evidence in terms of sediment retention. On the one hand, the volume of the dune is still a proxy of the sediment amount; on the other hand, the cover classes percentage, unless anthropic, is positively related to an increasing edge effect.

Sediment transport from north to south determines increasing size of the dunes, and such morphological evidence has also been investigated in the submerged beach of the same area, where nearshore sandy bars have been recognized and classified [66], suggesting further relations to be explored.

Vegetation patterns thus affect sand deposition, and conversely, the amount of deposition also affects the vegetation patch distribution $[1,67]$. It is worth noting that the lag analyses weight the border effect introduced by the width and length ratio of each lag. The uncertainty, due to the fact that the transect line border does not match with the natural borders of the polygon patches used for fragmentation metric calculation, was estimated to be between $3.5 \%$ and $5.5 \%$ on average.

The vegetation cover distribution of the foredune has a discontinuous pattern due to anthropic features such as the coastal road overlapping the dune crest and the walkways and paths crossing the dune. These features are triggering factors for instability phenomena such as natural blowout openings, erosion furrows, and runoff (Figure 14).
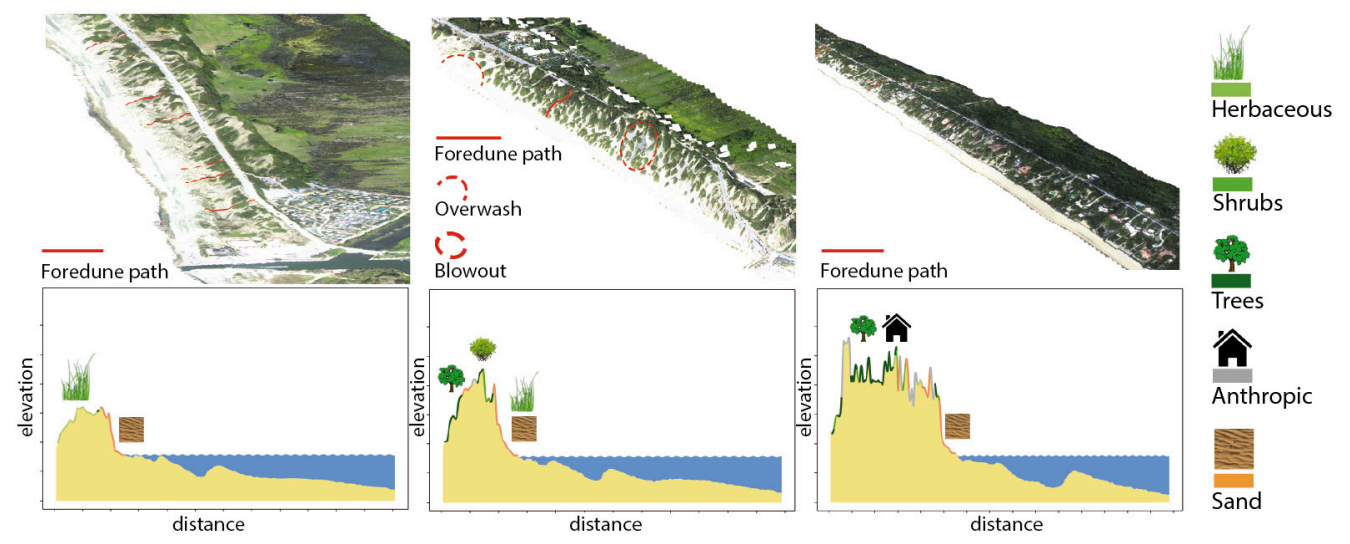

Figure 14. (top) 3D topographic LiDAR visualization of the beach-dune system from north to south and (down) corresponding details of the analyses provided by plotting on the DSM profiles the cover typologies (submerged beach profiles are also shown to give a better view of the system [66]).

In the foredune, there is a variable distribution of shrubs that, in a specific part of the stretch, are almost absent (Figure 8). This can be the indicator for blowouts and for a less stabilized portion of the stretch, where the vegetation does not respect an along-shore gradient, as expected. Within the foredune, the herbaceous cover percentage and its distribution increases southward and is inversely correlated with shrub percentage.

The dune slope facing the sea shows more discontinuous vegetation cover compared to the slope facing the lagoons. High vegetation cover is detectable close to the coastal road but generally does not have more than $75 \%$ of abundance. We did not find a strong correlation between the dune slope and dune cover. The foredune slope is covered by vegetation typical of the not-yet-consolidated dune, forming a discontinuous layer of elevation of a few decimeters on top of the topography only in the central part. Moving south, these vegetation formations are characterized by the presence of pioneer juniper, which represents the transition between herbaceous phytocoenoses and those of the Mediterranean coastal vegetation of consolidated dunes. 
Moreover, the foot sinuosity along the dune ridge is naturally related to different vegetation typologies and wind-blown effects, but here, the inverse correlation between the foredune anthropic cover and sinuosity values is driven by the presence of linear fences that separate the public beaches from private properties. In the southern part of the stretch, the foredune foot has a higher sinuosity value due to the higher width of the beach and the dune elevation, but anthropic cover artificially prevents natural sinuosity that is associated with the presence of pioneering vegetation between 15.5 and $17.5 \mathrm{~km}$ (Figure 13). In general, the whole foot system has a very highly scattered pattern in terms of sinuosity associated with beach cleaning and management activities (mainly in the summer period) and private villa garden maintenance (all the year). This leads to signature evidence of the Anthropocene because the presence of anthropic structures is mainly referable to the construction of the coastal road on the dune crest and houses in the southern part of the dune. It is argued that the Anthropocene is set in the mid-20th century when the "Great Acceleration" and "world-wide distribution" of several markers of human activities are found in the atmosphere and on land (radioactive fallout from the Trinity test in 1945, increase in aluminum, tarmac, and concrete production, decrease in many species) [68,69]. Surprisingly, we also found evidence of anthropogenic influence on the beach-dune system morphology in the study area where, close to the dune foot, sandy areas are dominant and are exposed with patchy distributions; moving south, the sand is interspersed with plant communities. Nevertheless, anthropic cover is more abundant in the southern foredune and the lower sinuosity is extended along the entire stretch, highlighting the fingerprint of human activities (e.g., removal of pioneering species at the foredune foot and levelling of the emerged beach before and during the summer).

The effective and innovative contribution of the present study to the traditional approaches based on ecomorphological monitoring is in the use of landscape ecology indexes to map and explain land cover spatial patterns [26].

\section{Conclusions}

The synergy among airborne hyperspectral-derived and altimetry-derived data, and in situ measurements for the vegetation and sand cover distributions, support the idea that the whole system scale can be captured in its entirety, preserving the details of the individual components. This approach will help future cross-scale monitoring activities because of its reliability in terms of data collection and method to process these data. It integrates the traditional method of extracting dune metrics with innovative theories of feedback between landscape ecology and geomorphology.

The results obtained have enabled us to produce thematic maps and calculate parameters and indices that describe and quantify the spatial distribution of sand cover within the coastal dune landforms. Significant north-south gradients related to beach and dune width, elevation, and the profile underlying the surface, as well as fragmentation of the landscape, were observed in the study area. The ecomorphological patterns have highlighted the signatures of vegetation and sand distribution as leading components of the dune landscape.

The significant advance exposes a valuable procedure to determine the sediment retention bionetwork stressed particularly by the intensive coastal dune exploitation and, subsequently, the Anthropocene fingerprint due to human activities.

Supplementary Materials: The following are available online at http://www.mdpi.com/2072-4292/12/8/1229/s1. S1. Correlation matrix for the dune, based on the forty variables selected. S2. Correlation matrix for the foredune, based on the forty variables selected.

Author Contributions: Conceptualization, E.V. and A.T.; Data curation, E.V., F.F. and A.N.X.; Formal analysis, E.V., A.T., S.C., F.F. and A.N.X.; Investigation, E.V., A.T., S.C. and A.N.X.; Methodology, E.V., F.F. and A.N.X.; Project administration, A.T.; Resources, A.T. and E.V.; Supervision, E.V., A.T. and S.C.; Validation, E.V.; Visualization, E.V., A.N.X. and F.F.; Writing—original draft, E.V., A.T. and S.C.; Writing—review \& editing, E.V., A.T., S.C., F.F. and A.N.X. All authors have read and agreed to the published version of the manuscript. 
Funding: The research was funded by the Lazio Region Authority (Italy) within the CAMP-LIDLAZ Project (2009) and by the Italian Institute for Environmental Protection and Research (ISPRA) under the agreement with the Italian Space Agency (Agreement number A0HMASI2).

Acknowledgments: Special thanks is addressed to Eng. Paolo Lupino for his interest and support.Thanks for the contribution to the achievement of this work goes to ISPRA colleagues during LIDLAZ project, Matteo Conti, Elena Pallottini, Raffaele Proietti and Lorenzo Rossi.

Conflicts of Interest: The authors declare no conflict of interest.

\section{References}

1. Baas, A.C.W.; Nield, J.M. Modelling vegetated dune landscapes. Geophys. Res. Lett. 2007, 34. [CrossRef]

2. Barchyn, T.E.; Hugenholtz, C.H. Predicting vegetation-stabilized dune field morphology. Geophys. Res. Lett. 2013, 39. [CrossRef]

3. Barchyn, T.E.; Hugenholtz, C.H. Reactivation of supply-limited dune fields from blowouts: A conceptual framework for state characterization. Geomorphology 2013, 201, 172-182. [CrossRef]

4. Baas, A.C.W. Chaos, fractals and self-organization in coastal geomorphology: Simulating dune landscapes in vegetated environments. Geomorphology 2002, 48, 309-328. [CrossRef]

5. Baas, A.C.W. Complex systems in aeolian geomorphology. Geomorphology 2007, 91, 311-331. [CrossRef]

6. Kocurek, G.; Ewing, R.C. Aeolian dune field self-organization-implications for the formation of simple versus complex dune-field patterns. Geomorphology 2005, 72, 94-105. [CrossRef]

7. Martínez, M.L.; Psuty, N.P.; Lubke, R.A. A Perspective on Coastal Dunes. In Coastal Dunes; Springer: Berlin/Heidelberg, Germany, 2008; pp. 3-10. [CrossRef]

8. Ciccarelli, D.; Pinna, M.S.; Alquini, F.; Cogoni, D.; Ruocco, M.; Bacchetta, G.; Sarti, G.; Fenu, G. Development of a coastal dune vulnerability index for Mediterranean ecosystem: A useful tool for coastal managers? Estuar. Coast. Shelf Sci. 2017, 187, 84-95. [CrossRef]

9. Corbau, C.; Simeoni, U.; Melchiorre, M.; Rodella, I.; Utizi, K. Regional variability of coastal dunes observed along the Emilia Romagna littoral Italy. Aeolian Res. 2015, 18, 169-183. [CrossRef]

10. Hesp, P.A. A review of biological and geomorphological processes involved in the initiation and development of incipient foredunes. Proc. R. Soc. Edinb. 1989, 96, 181-201. [CrossRef]

11. Hesp, P.A. Ecological processes and plant adaptations on coastal dunes. J. Arid Environ. 1991, 21, $165-191$. [CrossRef]

12. McAuliffe, J.R.; Hamerlynck, E.P.; Eppes, M.C. Landscape dynamics fostering the development and persistence of long-lived creosotebush (Larrea tridentata) clones in the Mojave desert. J. Arid Environ. 2007, 69, 96-126. [CrossRef]

13. Keijsers, J.G.S.; De Groot, A.V.; Riksen, M.J.P.M. Vegetation and sedimentation on coastal foredunes. Geomorphology 2015, 228, 723-734. [CrossRef]

14. Duran, O.; Moore, L.J. Vegetation controls on the maximum size of coastal dunes. Proc. Natl. Acad. Sci. USA 2013, 110, 17217-17222. [CrossRef] [PubMed]

15. Zhang, L.; Baas, A.C. Mapping functional vegetation abundance in a coastal dune environment using a combination of LSMA and MLC: A case study at Kenfig NNR, Wales. Int. J. Remote Sens. 2012, 33, 5043-5071. [CrossRef]

16. Lancaster, N.; Baas, A. Influence of vegetation cover on sand transport by wind: Field studies at Owens Lake, California. Earth Surf. Proc. Land. 1998, 23, 69-82. [CrossRef]

17. Leenders, J.K.; Sterk, G.; Van Boxel, J.H. Modelling wind-blown sediment transport around single vegetation elements. Earth Surf. Proc. Land. 2011, 36, 1218-1229. [CrossRef]

18. Pelletier, J.D.; Mitasova, H.; Harmon, R.S.; Overton, M. The effects of interdune vegetation changes on eolian dune field evolution: A numerical modeling case study at Jockey's ridge, North Carolina, USA. Earth Surf. Proc. Land. 2009, 34, 1245-1254. [CrossRef]

19. Nickling, W.G.; Neuman, C.M. Aeolian sediment transport. In Geomorphology of Desert Environments; Springer: Dordrecht, The Netherlands, 2009; pp. 517-555.

20. Acosta, A.; Carranza, M.L.; Izzi, C.F. Combining land cover mapping of coastal dunes with vegetation analysis. Appl. Veg. Sci. 2005, 8, 133-138. [CrossRef] 
21. Acosta, A.; Ercole, S.; Stanisci, A.; Pillar, V.D.P.; Blasi, C. Coastal vegetation zonation and dune morphology in some Mediterranean ecosystems. J. Coast. Res. 2007, 1518-1524. [CrossRef]

22. Mason, D.C.; Scott, T.R.; Dance, S.L. Remote sensing of intertidal morphological change in Morecambe Bay, U.K., between 1991 and 2007. Estuar. Coast. Shelf Sci. 2010, 87, 487-496. [CrossRef]

23. Jones, T.G.; Coops, N.C.; Sharma, T. Assessing the utility of airborne hyperspectral and LiDAR data for species distribution mapping in the coastal Pacific Northwest, Canada. Remote Sens. Environ. 2010, 114, 2841-2852. [CrossRef]

24. Zalasiewicz, J.; Waters, C.N.; Head, M.J.; Poirier, C.; Summerhayes, C.P.; Leinfelder, R.; Grinevald, J.; Steffen, W.; Syvitski, J.P.M.; Haff, P.; et al. A formal Anthropocene is compatible with but distinct from its diachronous anthropogenic counterparts: A response to W.F. Ruddiman's 'three-flaws in defining a formal Anthropocene'. Prog. Phys. Geog. 2019, 43, 319-333. [CrossRef]

25. Cappucci, S.; Scarcella, D.; Rossi, L.; Taramelli, A. Integrated Coastal Zone Management at Marina di Carrara Harbor: Sediment management and policymaking. Ocean Coast. Manag. 2011, 54, 277-289. [CrossRef]

26. Pelletier, J.D.; Brad Murray, A.; Pierce, J.L.; Bierman, P.R.; Breshears, D.D.; Crosby, B.T.; Ellis, M.; Foufoula-Georgiou, E.; Heimsath, A.M.; Houser, C.; et al. Forecasting the response of Earth's surface to future climatic and land use changes: A review of methods and research needs. Earth's Future 2015, 3, 220-251. [CrossRef]

27. Yousefi Lalimi, F.; Silvestri, S.; Moore, L.J.; Marani, M. Coupled topographic and vegetation patterns in coastal dunes: Remote sensing observations and ecomorphodynamic implications. J. Geophys. Res. Biogeosci. 2017, 122, 119-130. [CrossRef]

28. Ibrahim, E.; Monbaliu, J. Suitability of spaceborne multispectral data for inter-tidal sediment characterization: A case study. Estuar. Coast. Shelf Sci. 2011, 92, 437-445. [CrossRef]

29. Jin, H.X.; Eklundh, L. A physically based vegetation index for improved monitoring of plant phenology. Remote Sens. Environ. 2014, 152, 512-525. [CrossRef]

30. Mancini, F.; Dubbini, M.; Gattelli, M.; Stecchi, F.; Fabbri, S.; Gabbianelli, G. Using un- manned aerial vehicles (UAV) for high-resolution reconstruction of topography: The structure from motion approach on coastal environments. Remote Sens. 2013, 5, 6880-6898. [CrossRef]

31. Valentini, E.; Taramelli, A.; Filipponi, F.; Giulio, S. An effective procedure for EUNIS and Natura 2000 habitat type mapping in estuarine ecosystems integrating ecological knowledge and remote sensing analysis. Ocean Coast. Manag. 2015, 108, 52-64. [CrossRef]

32. Taramelli, A.; Valentini, E.; Cornacchia, L.; Bozzeda, F. A hybrid power law approach for spatial and temporal pattern analysis of salt marsh evolution. J. Coast. Res. 2017, 77, 62-72. [CrossRef]

33. Cracknell, A. Remote sensing techniques in estuaries and coastal zones an update. Int. J. Remote Sens. 1999, 20, 485-496. [CrossRef]

34. Mumby, P.J.; Edwards, A.J. Mapping marine environments with IKONOS imagery-Enhanced spatial resolution can deliver greater thematic accuracy. Remote Sens. Environ. 2002, 82, 248-257. [CrossRef]

35. Taramelli, A.; Valentini, E.; Cornacchia, L.; Monbaliu, J.; Sabbe, K. Self-organized processes between salt marsh vegetation patterns and channel network in a tidal landscape. J. Geophys. Res.-Earth 2018, 123, 2714-2731. [CrossRef]

36. Manzo, C.; Valentini, E.; Taramelli, A.; Filipponi, F.; Disperati, L. Spectral characterization of coastal sediments using Field Spectral Libraries, Airborne Hyperspectral Images and Topographic LiDAR Data (FHyL). Int. J. Appl. Earth Obs. 2015, 36, 54-68. [CrossRef]

37. Cappucci, S.; Valentini, E.; Del Monte, M.; Paci, M.; Filipponi, F.; Taramelli, A. Detection of natural and anthropic features on small islands. J. Coast. Res. 2017, 77, 74-88. [CrossRef]

38. Zhang, X.; Liao, C.; Li, J.; Sun, Q. Fractional vegetation cover estimation in arid and semi-arid environments using HJ-1 satellite hyperspectral data. Int. J. Appl. Earth Obs. 2013, 21, 506-512. [CrossRef]

39. Rainey, M.P.; Tyler, A.N.; Gilvear, D.J.; Bryant, R.G.; McDonald, P. Mapping intertidal estuarine sediment grain size distributions through airborne remote sensing. Remote Sens. Environ. 2003, 86, 480-490. [CrossRef]

40. Small, C.; Steckler, M.; Seeber, L.; Akhter, S.H.; Goodbred, S., Jr.; Mia, B.; Imam, B. Spectroscopy of sediments in the Ganges-Brahmaputra delta: Spectral effects of moisture, grain size and lithology. Remote Sens. Environ. 2009, 113, 342-361. [CrossRef] 
41. Bazzichetto, M.; Malavasi, M.; Acosta, A.T.R.; Carranza, M.L. How does dune morphology shape coastal EC habitats occurrence? A remote sensing approach using airborne LiDAR on the Mediterranean coast. Ecol. Indic. 2016, 71, 618-626. [CrossRef]

42. Brock, J.C.; Purkis, S.J. The emerging role of lidar remote sensing in coastal research and resource management. J. Coast. Res. 2009, 1-5. [CrossRef]

43. Sallenger, A.H., Jr.; Krabill, W.B.; Swift, R.N.; Brock, J.; List Mark Hansen, J.; Holman, R.A.; Manizade, S.; Sontag, J.; Meredith, A.; Morgan, K.; et al. Evaluation of airborne topographic Lidar for quantifying beach changes. J. Coast. Res. 2003, 19, 125-133.

44. Chust, G.; Galparsoro, I.; Borja, A.; Franco, J.; Uriarte, A. Coastal and estuarine habitat mapping, using LIDAR height and intensity and multi-spectral imagery. Estuar. Coast. Shelf Sci. 2008, 78, 633-643. [CrossRef]

45. Taramelli, A.; Valentini, E.; Innocenti, C.; Cappucci, S. FHyL: Field spectral libraries, airborne hyperspectral images and topographic and bathymetric LiDAR data for complex coastal mapping. Geoscience and Remote Sensing Symposium (IGARSS). In Proceedings of the 2013 IEEE International Geoscience and Remote Sensing Symposium-IGARSS, Melbourne, Australia, 21-26 July 2013; pp. 2270-2273. [CrossRef]

46. Pascucci, V.; De Falco, G.; Del Vais, C.; Melis, R.; Sanna, I.; Andreucci, S. Climate Changes And Human Impact on The Mistras Coastal Barrier System (W Sardinia, Italy). Mar. Geol. 2018, 395, 271-284. [CrossRef]

47. Pascucci, V.; Frulio, G.; Andreucci, S. New estimation of the post Little Ice Age Relative Sea Level Rise. Geosciences 2019, 9, 348. [CrossRef]

48. Campo, V.; La Monica, G.B. Le dune costiere oloceniche prossimali lungo il litorale del Lazio. Studi Costieri 2006, 11, 31-42.

49. Carboni, M.; Santoro, R.; Acosta, A.T.R. Are some communities of the coastal dune zonation more susceptible to alien plant invasion? J. Plant. Ecol. 2010, 3, 139-147. [CrossRef]

50. Pascucci, V.; Cappucci, S.; Andreucci, S.; Donda, F. Sedimentary features of the offshore part of the la Pelosa Beach (Sardinia, Italy). Rend. Line Soc. Geol. Ital. 2008, 2, 1-3.

51. Pallottini, E.; Cappucci, S. Beach-Dune system interaction and evolution. Rend. Soc. Geo. Ital. 2009, 8, 87-97.

52. Conti, M.; Cappucci, S.; La Monica, G.B. Sediment dynamic of nourished sandy beaches. Rend. Line Soc. Geol. Ital. 2009, 8, 31-38.

53. Quadros, N.D.; Collier, P.A.; Fraser, C.S. Integration of bathymetric and topographic LiDAR: A preliminary investigation. ISPRS J. Photogramm. Remote Sens. 2008, 37, 1299-1304.

54. Allegrini, A.; Anselmi, S.; Cavalli, R.M.; Manes, F.; Pignatti, S. Multiscale integration of satellite, airborne and field data for Mediterranean vegetation studies in the natural area of the Castelporziano Estate (Rome). Ann. Geophys. 2005, 49, 167-175.

55. Innocenti, C.; Filipponi, F.; Valentini, E.; Taramelli, A. Multisensory data fusion methods for the estimation of beach sediment features: Mineralogical, grain size and moisture, Geoscience and Remote Sensing Symposium (IGARSS). In Proceedings of the 2013 IEEE International Geoscience and Remote Sensing Symposium-IGARSS, Melbourne, Australia, 21-26 July 2013; pp. 3064-3067. [CrossRef]

56. Sorichetta, A.; Seeber, L.; Taramelli, A.; McHugh, C.M.G.; Cormier, M.H. Geomorphic evidence for tilting at a continental transform: The Karamusel basin along the North Anatolian Fault, Turkey. Geomorphology 2010, 119, 221-231. [CrossRef]

57. Sousa, D.; Small, C. Global cross-calibration of Landsat spectral mixture models. Remote Sens. Environ. 2017, 192, 139-149. [CrossRef]

58. Small, C. The Landsat ETM+ spectral mixing space. Remote Sens. Environ. 2004, 93, 1-17. [CrossRef]

59. Combe, J.P.; Launeau, P.; Carrère, V.; Despan, D.; Méléder, V.; Barillé, L.; Sotin, C. Mapping microphytobenthos biomass by non-linear inversion of visible-infrared hyperspectral images. Remote Sens. Environ. 2005, 98, 371-387. [CrossRef]

60. Roberts, D.; Green, R.; Adams, J. Temporal and spatial patterns in vegetation and atmospheric properties from AVIRIS. Remote Sens. Environ. 1997, 62, 223-240. [CrossRef]

61. Metternicht, G.; Fermont, A. Estimating erosion surface features by linear mixture modeling. Remote Sens. Environ. 1998, 64, 254-265. [CrossRef]

62. McGarigal, K.; Cushman, S.A.; Ene, E. FRAGSTATS v4: Spatial Pattern Analysis Program for Categorical and Continuous Maps. University of Massachusetts, Amherst. Computer Software Program Produced by 
the Authors at the Uni-versity of Massachusetts. 2012. Available online: https://www.umass.edu/landeco/ research/fragstats/fragstats.html (accessed on 8 April 2020).

63. Pallottini, E.; Cappucci, S.; Taramelli, A.; Innocenti, C.; Screpanti, A. Variazioni morfologiche stagionali del sistema spiaggia-duna del Parco Nazionale del Circeo. Studi Costieri 2010, 17, 105-124.

64. Baas, A.C.; Nield, J.M. Ecogeomorphic state variables and phase-space construction for quantifying the evolution of vegetated aeolian landscapes. Earth Surf. Proc. Land. 2010, 35, 717-773. [CrossRef]

65. Finkl, C.W. Coastal classification: Systematic approaches to consider in the development of a comprehensive scheme. J. Coast. Res. 2003, 20, 166-213. [CrossRef]

66. Taramelli, A.; Cappucci, S.; Valentini, E.; Rossi, L.; Lisi, I. Nearshore Sandbar Classification of Sabaudia (Italy) with LiDAR Data: The FHyL Approach. Remote Sens. 2020, 12, 1053. [CrossRef]

67. Nield, J.M.; Baas, A.C.W. The influence of different environmental and climatic conditions on vegetated aeolian dune landscape development and response. Glob. Planet. Change 2008, 64, 76-92. [CrossRef]

68. Williams, M.; Zalasiewicz, J.; Waters, N.C.; Leinfelder, R. The palaeontological record of the Anthropocene. Geol. Today 2018, 34, 188-193. [CrossRef]

69. Lewis, S.L.; Maslin, M.A. Defining the Anthropocene. Nature 2015, 519, 171-180. [CrossRef] [PubMed]

(C) 2020 by the authors. Licensee MDPI, Basel, Switzerland. This article is an open access article distributed under the terms and conditions of the Creative Commons Attribution (CC BY) license (http://creativecommons.org/licenses/by/4.0/). 